\title{
Physical drivers of the nitrate seasonal variability in the Atlantic cold tongue
}

\author{
Marie-Hélène Radenac ${ }^{1}$, Julien Jouanno ${ }^{1}$, Christine Carine Tchamabi ${ }^{1, \dagger}$, Mesmin Awo ${ }^{1,2,3}$, Bernard Bourlès ${ }^{4}$, \\ Sabine Arnault ${ }^{5}$, and Olivier Aumont ${ }^{5}$ \\ ${ }^{1}$ LEGOS, IRD-Université Paul Sabatier-Observatoire Midi-Pyrénées, Toulouse, 31400, France \\ ${ }^{2}$ Nansen-Tutu Centre for Marine Environmental Research, Department of Oceanography, \\ University of Cape Town, Cape Town, South Africa \\ ${ }^{3}$ LHMC, IRHOB, IRD, Cotonou, Benin \\ ${ }^{4}$ IRD, US191 "Instrumentation, Moyens Analytiques, Observatoires en Géophysique et Océanographie" (IMAGO), \\ Technopole Pointe du Diable, Plouzané, France \\ ${ }^{5}$ LOCEAN, CNRS, IRD, Sorbonne Universités, MNHN, Paris, 75005, France \\ $\dagger$ deceased
}

Correspondence: Marie-Hélène Radenac (marie-helene.radenac@legos.obs-mip.fr)

Received: 26 August 2019 - Discussion started: 18 September 2019

Revised: 18 December 2019 - Accepted: 24 December 2019 - Published: 31 January 2020

\begin{abstract}
Ocean color observations show semiannual variations in chlorophyll in the Atlantic cold tongue with a main bloom in boreal summer and a secondary bloom in December. In this study, ocean color and in situ measurements and a coupled physical-biogeochemical model are used to investigate the processes that drive this variability. Results show that the main phytoplankton bloom in July-August is driven by a strong vertical supply of nitrate in May-July, and the secondary bloom in December is driven by a shorter and moderate supply in November. The upper ocean nitrate balance is analyzed and shows that vertical advection controls the nitrate input in the equatorial euphotic layer and that vertical diffusion and meridional advection are key in extending and shaping the bloom off Equator. Below the mixed layer, observations and modeling show that the Equatorial Undercurrent brings low-nitrate water (relative to off-equatorial surrounding waters) but still rich enough to enhance the cold tongue productivity. Our results also give insights into the influence of intraseasonal processes in these exchanges. The submonthly meridional advection significantly contributes to the nitrate decrease below the mixed layer.
\end{abstract}

\section{Introduction}

Variations in the equatorial upwelling in the Atlantic Ocean are essentially seasonal. The so-called cold tongue spreads east of about $20^{\circ} \mathrm{W}$ to the African coast and is centered slightly south of the Equator (Carton and Zhou, 1997; Caniaux et al., 2011). The maximum cooling is reached in July-August and a secondary cooling occurs in NovemberDecember (Okumura and Xie, 2006). The cold tongue is a region of enhanced biological production mainly driven by nitrate supply (Voituriez and Herbland, 1977; Loukos and Mémery, 1999). There, the availability of nutrients affects the equatorial ecosystem from primary production to high trophic levels and $\mathrm{CO}_{2}$ fluxes (Hisard, 1973; Voituriez and Herbland, 1977; Oudot and Morin, 1987; Loukos and Mémery, 1999; Ménard et al., 2000; Christian and Murtugudde, 2003; Lefèvre, 2009). Early in situ measurements in the equatorial Atlantic (Hisard, 1973; Voituriez and Herbland, 1977) evidenced two seasons with different physical and biogeochemical conditions: (i) a warm and lowproductivity season in winter and spring with a nitratedepleted surface layer and a chlorophyll maximum located near the top of the nitracline and (ii) a cool and highproductivity season in summer and fall characterized by efficient vertical processes that bring cold and nitrate-rich 
water supporting the phytoplankton growth in the euphotic layer. The advent of ocean color satellite measurements has made the monitoring of phytoplankton blooms possible and changed our vision of the equatorial variability. Using 1 year (March 1979-February 1980) of measurements from the Coastal Zone Color Scanner (CZCS), Monger et al. (1997) showed a higher chlorophyll value (more than $1 \mathrm{mg} \mathrm{m}^{-3}$ ) in October-December than in summer near $10^{\circ} \mathrm{W}$. In contrast, during the first year of the Sea-viewing Wide Field-of-view Sensor (SeaWiFS), a bloom was observed between May and September, and the October-December chlorophyll values were low (Signorini et al., 1999). This suggests large interannual fluctuations of the equatorial productivity. Nevertheless, a semiannual cycle of surface chlorophyll emerges as illustrated by the ocean color archive for the period 19982016 (Fig. 1a). This seasonal cycle is characterized by a primary chlorophyll bloom in July-August between 20 and $5^{\circ} \mathrm{W}$ and a shorter and weaker second bloom in December (Pérez et al., 2005; Grodsky et al., 2008; Jouanno et al., 2011a). Strong similarities between this seasonal cycle and the seasonal cycle of sea surface temperature (SST) suggest that the same physical processes could control the supply of cool and nutrient-rich waters into the euphotic layer (Hisard, 1973; Oudot and Morin, 1987; Grodsky et al., 2008; Jouanno et al., 2011a).

Investigations of the link between physical processes and biological production in the equatorial Atlantic were conducted using in situ measurements during oceanographic cruises since the 1960s and satellite measurements since the 1980s. The role of upwelling, vertical mixing, and variation in the depth of the thermocline and nitracline has been raised to explain the seasonal surface nitrate and chlorophyll increase. Hisard (1973) proposed that nutrient enrichment at $5^{\circ} \mathrm{W}$ is mainly driven by the equatorial divergence in summer and persists until fall because of enhanced vertical mixing. The enhancement of the vertical mixing during the cold season was associated with the strong vertical shear between the intensified South Equatorial Current (SEC) and the shallower Equatorial Undercurrent (EUC) by Voituriez and Herbland (1977). Considering oxygen and salinity distributions, Voituriez (1983) dismissed the influence of vertical mixing and emphasized the role of the thermocline/nitracline uplift. Oudot and Morin (1987) suggested that the equatorial divergence drove the summer nitrate enrichment and that its persistence until fall was supported by vertical mixing above the EUC core whose nitrate concentration increased because of the nitracline uplift. Monger et al. (1997) proposed that upwelling was the driving mechanism of the summer and fall nitrate increase and that its efficiency was modulated by the relative depths of the EUC and nitracline. Grodsky et al. (2008) stressed the role of the equatorial upwelling combined with the shoaling of the nitracline.

Few model-based studies have addressed the influence of the ocean dynamics variability on the nutrient variability in the equatorial Atlantic. Loukos and Mémery (1999) used an offline nitrate transport model to examine the processes that drive nitrate to the surface. In their 2-year simulation, surface nitrate concentration and biological production are more elevated in summer and decrease afterwards, although they remain higher in fall-early winter than in spring. In summer, nitrate is brought to the EUC and euphotic layer through vertical advection and reaches the surface through vertical diffusion. Christian and Murtugudde (2003) ran a 50year-long coupled physical-biogeochemical model and underlined the influence of the relative depth between the nitracline and the upwelling core on the nitrate variations. In spring, the surface nitrate is at its lowest because the upwelling is weak and located above the nitracline. In contrast, surface nitrate peaks in summer when water is upwelled from the subsurface in response to the basin-wide tilt of the thermocline/nitracline. More recently, Jouanno et al. (2011a) related processes responsible for SST changes to the observed chlorophyll changes. They highlighted the semiannual cycle of vertical mixing above the EUC core driven by the semiannual variation in the SEC. Maximum vertical mixing and surface cooling occur concurrently in summer while the impact of vertical mixing can be strongly damped by air-sea heat fluxes during the secondary cooling in November-December. Because such a constraint does not exist for surface chlorophyll, intensified vertical mixing and surface chlorophyll peak simultaneously in summer and in November-December.

The impact of tropical instability waves (TIWs) on the ecosystem of the Atlantic cold tongue was proposed by Morlière et al. (1994) and Menkes et al. (2002). Although there is a debate about the influence of TIWs on the nutrient budget in the equatorial Pacific (Strutton et al., 2001; Gorgues et al., 2005), no such study is available in the equatorial Atlantic where TIWs dominate the intraseasonal variability in the western and central basins and wind-forced waves dominate in the east (Athié and Marin, 2008).

This study was motivated by observation of the nitrate vertical patterns during the low- and high-productivity seasons by repeated in situ measurements along $10^{\circ} \mathrm{W}$ acquired during recent cruises and their link with the semiannual variability of chlorophyll observed by ocean color satellites. Because cruise sampling prevents us from studying an entire seasonal cycle, a coupled physical-biogeochemical simulation is used to complement the nitrate and chlorophyll seasonal cycles and to investigate the processes driving this seasonality. The data sets we use and the coupled physical-biogeochemical model are described in Sect. 2. Previous studies have shown that vertical processes (equatorial upwelling, vertical mixing, and vertical motion of the nitracline) are involved in setting the seasonal cycles of surface nitrate and chlorophyll. However, it is not clear how these vertical processes combine with horizontal processes to drive the bloom properties in terms of spatial extent and duration. This issue is investigated by analyzing the model seasonal nitrate budget (Sect. 3 ). The role of the variation in nitrate concentration in the EUC in the ni- 
trate budget in the euphotic layer and the impact of transient processes such as TIWs and wind-forced waves are discussed in Sect. 4. Concluding remarks are presented in Sect. 5.

\section{In situ and satellite observations}

\subsection{Data sets}

We use in situ nitrate, chlorophyll, and acoustic Doppler current profiler (ADCP) measurements collected during repeated transects along $10^{\circ} \mathrm{W}$ (Table 1 ) as part of the PIRATA (Prediction and Research Moored Array in the Tropical Atlantic; Servain et al., 1998; Bourlès et al., 2008, 2019) and EGEE (Étude de la Circulation Océanique et de sa Variabilité dans le Golfe de Guinée; Bourlès et al., 2007) programs. All these data, along with information on their acquisition and treatment, are available through their DOI (Bourlès, 1997; Bourlès et al., 2018a, c). The analysis is based on 13 transects with nitrate measurements between 2004 and 2014 and four transects with chlorophyll measurements corresponding to the most recent French PIRATA cruises from 2011 to 2014. If we simply consider that upwelling conditions prevail when nitrate concentration larger than $1 \mu \mathrm{mol} \mathrm{L}^{-1}$ is measured in the upper $10 \mathrm{~m}$ between $2^{\circ} \mathrm{S}$ and $1^{\circ} \mathrm{N}$, only two cruises fulfill these conditions (June 2005 and July 2009). Note that there are no chlorophyll measurements during the boreal summer upwelling period.

Observations from a PIRATA ocean-atmosphere interaction mooring and an ADCP mooring maintained at $10^{\circ} \mathrm{W}-$ $0^{\circ} \mathrm{N}$ (Bourlès et al., 2018b) are also analyzed. We use monthly temperature measurements available since September 1997 at 1, 5, 10, 20, 40, 60, 80, 100, 120, 140, 180, 300, and $500 \mathrm{~m}$ depth and daily ADCP current profiles available every $5 \mathrm{~m}$ from $15 \mathrm{~m}$ to about $300 \mathrm{~m}$ depth between December 2001 and March 2017.

The climatology of surface chlorophyll is calculated from chlorophyll estimates at $25 \mathrm{~km}$ horizontal resolution of the monthly GlobColour merged product obtained from different sensors and using the GSM (Garver, Siegel, Maritorena) model described in Maritorena et al. (2010). Sensors are Medium Resolution Imaging Spectrometer (MERIS), SeaWiFS, Moderate Resolution Imaging Spectroradiometer (MODIS) Aqua, and the Visible and Infrared Imager/Radiometer Suite (VIIRS) when available.

The SST climatology is derived from the TropFlux data set (Praveen Kumar et al., 2012). We use monthly SST maps from 1979 to 2016 at $1^{\circ} \times 1^{\circ}$ resolution between $30^{\circ} \mathrm{S}$ and $30^{\circ} \mathrm{N}$.

\subsection{Observed seasonal cycles}

Correspondences between spatial patterns and seasonal cycles of the surface chlorophyll and those of SST are illustrated in Fig. 1. In July-August, when the cold tongue expansion is the largest, the distribution of surface chlorophyll mirrors the SST distribution (Fig. 1b). The minimum SST and maximum surface chlorophyll coincide and are located south of the Equator between 20 and $5^{\circ} \mathrm{W}$. Chlorophyll and SST gradients are sharper on the northern side of the cold tongue than on the southern side. The surface chlorophyll value starts to increase in May (Fig. 1a), and the chlorophyll maximum and SST minimum are found in July-August and in December. The December peak is better defined with chlorophyll than with temperature. The surface chlorophyll is at its minimum in spring, and a secondary minimum occurs in October.

Vertical sections of nitrate, chlorophyll, and zonal current along $10^{\circ} \mathrm{W}$ measured during the PIRATA cruises and averaged separately in no-upwelling-low-productivity and upwelling-high-productivity (Table 1) seasons are shown in Fig. 2a-c. Results are close to the distributions during the cold and warm seasons described along $4^{\circ} \mathrm{W}$ in the 1970s and 1980s (Voituriez and Herbland, 1977; Oudot, 1983; Monger et al., 1997) and along $10^{\circ} \mathrm{W}$ during the June and September 2005 EGEE cruises (Nubi et al., 2016). During the warm and low-productivity season, the low-chlorophyll (Fig. 2b) and nitrate-depleted (Fig. 2a) layer extends from the surface to $30 \mathrm{~m}$ between $1^{\circ} \mathrm{N}$ and $5^{\circ} \mathrm{S}$ and deepens southward. Below, a nitracline ridge is observed between 2 and $5^{\circ} \mathrm{S}$. The deep chlorophyll maximum (DCM) is located in the upper nitracline and intensifies between $5^{\circ} \mathrm{S}$ and $2^{\circ} \mathrm{N}$. During the cold and high-productivity season, the nitracline is uplifted and nitrate reaches the surface (Fig. 2c). The EUC transports water with low-nitrate concentration compared to off-equatorial waters at the same depth (Fig. 2a, c; Oudot, 1983) for both seasons.

Previous studies have shown that the location of the thermocline/nitracline relative to the EUC depth impacted the efficiency of the upwelling (Monger et al., 1997; Christian and Murtugudde, 2003). Figure 2d illustrates the seasonal vertical excursions of the thermocline and EUC as deduced from the temperature and zonal current profiles measured at the $0^{\circ} \mathrm{N}, 10^{\circ} \mathrm{W}$ PIRATA mooring. Seasonal variations in the depth of the EUC core are small while the thermocline depth shows larger vertical movements. The thermocline is about $20 \mathrm{~m}$ below the EUC core in April and about $30 \mathrm{~m}$ above in August, leading to variations in the properties of the EUC water. The temperature is colder in the EUC in August than during spring. Likewise, nitrate is more elevated in the EUC in August than during spring (Oudot and Morin, 1987), as expected from the strong relationship between nitrate and temperature in the nitracline of the cold tongue all year long (Voituriez and Herbland, 1984). 
Table 1. List of PIRATA (FR) and EGEE transects along $10^{\circ} \mathrm{W}$ and availability of $\mathrm{NO}_{3}$, chlorophyll, and ADCP zonal current measurements. Cruises used during the no-upwelling and upwelling periods are indicated in the last two columns.

\begin{tabular}{llllllc}
\hline & Dates & $\mathrm{NO}_{3}$ & $\mathrm{Chl}$ & $U$ & No-upwelling period & Upwelling period \\
\hline FR12 & February 2004 & $\times$ & & $\times$ & $\times$ & \\
FR14-EGEE1 & June 2005 & $\times$ & & $\times$ & & $\times$ \\
EGEE2 & September 2005 & $\times$ & & $\times$ & & $\times$ \\
FR15-EGEE3 & June 2006 & $\times$ & & $\times$ & & $\times$ \\
EGEE4 & November 2006 & $\times$ & & & & $\times$ \\
FR17-EGEE5 & June 2007 & $\times$ & & $\times$ & & $\times$ \\
EGEE6 & September 2007 & $\times$ & & & & $\times$ \\
FR19 & July 2009 & $\times$ & & & & $\times$ \\
FR20 & September 2010 & $\times$ & & & & $\times$ \\
FR21 & May 2011 & $\times$ & $\times$ & $\times$ & & $\times$ \\
FR22 & April 2012 & $\times$ & $\times$ & $\times$ & & $\times$ \\
FR23 & May 2013 & $\times$ & $\times$ & $\times$ & & $\times$ \\
FR24 & April 2014 & $\times$ & $\times$ & $\times$ & & \\
\hline
\end{tabular}
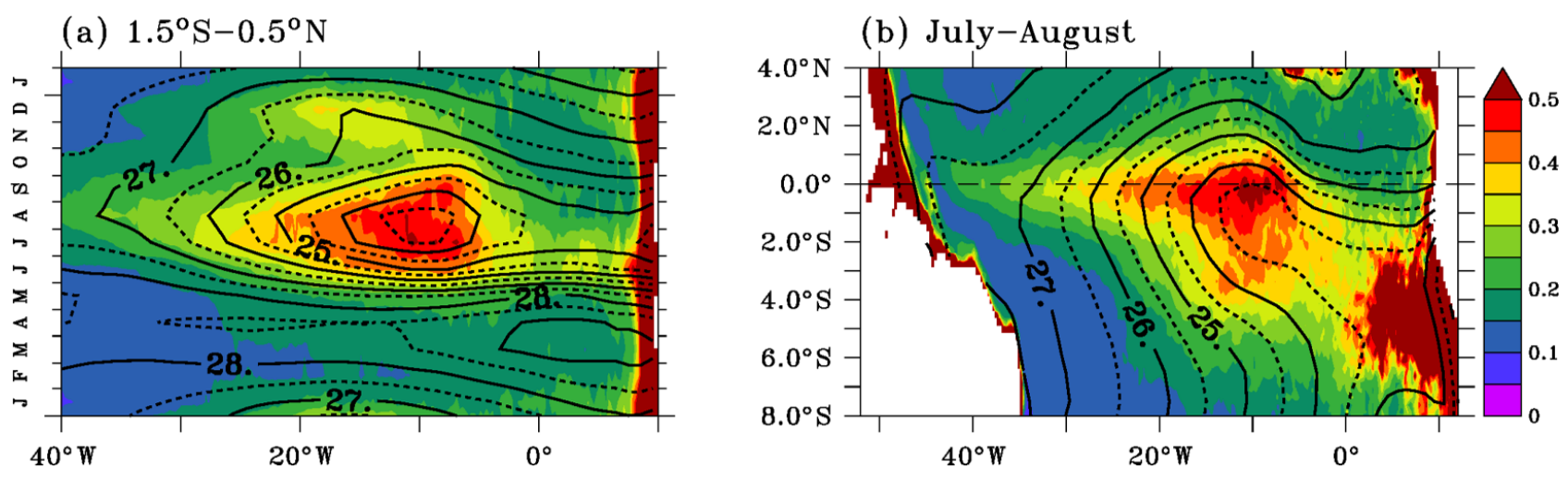

Figure 1. Seasonal cycles averaged in the upwelling region (a) and mean distributions in July-August (b) of satellite chlorophyll (mg $\mathrm{m}^{-3}$; colors) and observed SST $\left({ }^{\circ} \mathrm{C}\right.$; contours). Data were averaged between $1.5^{\circ} \mathrm{S}$ and $0.5^{\circ} \mathrm{N}$ in (a). The SST contour interval is $0.5^{\circ} \mathrm{C}$. Chlorophyll and SST climatologies are calculated over 1998-2015. See the data section for origin of data.

\section{Coupled physical-biogeochemical simulation}

\subsection{Model description}

A coupled simulation is used to describe the nitrate seasonal cycle and the seasonal nitrate budget in the mixed and euphotic layers. The physical component of the simulation is based on the NEMO (Nucleus for European Modeling of the Ocean; Madec and the NEMO team, 2016) numerical code. We use the regional configuration described in Hernandez et al. $(2016,2017)$ that covers the tropical Atlantic between $35^{\circ} \mathrm{S}$ and $35^{\circ} \mathrm{N}$ and from $100^{\circ} \mathrm{W}$ to $15^{\circ} \mathrm{E}$. The resolution of the horizontal grid is $1 / 4^{\circ}$ and there are 75 vertical levels, 24 of which are in the upper $100 \mathrm{~m}$ layer. The depth interval ranges from $1 \mathrm{~m}$ at the surface to about $10 \mathrm{~m}$ at $100 \mathrm{~m}$ depth. Interannual atmospheric fluxes of momentum, heat, and freshwater are derived from the DFS5.2 product (Dussin et al., 2016) using bulk formulae from Large and Yeager (2009). Temperature, salinity, current, and sea level from the
MERCATOR global reanalysis GLORYS2V4 (Storto et al., 2018) are used to force the model at the lateral boundaries.

The physical model is coupled to the PISCES (Pelagic Interaction Scheme for Carbon and Ecosystem Studies) biogeochemical model (Aumont et al., 2015) that simulates the biological production and the biogeochemical cycles of carbon, nitrogen, phosphorus, silica, and iron. Two phytoplankton classes (nanophytoplankton and diatoms) differ by their silicate and iron requirements. The two zooplankton compartments (nanozooplankton and mesozooplankton) feed on the two phytoplankton classes. The model also includes three nonliving compartments (dissolved organic matter and small and large sinking particles). The biogeochemical model is initialized and forced at the lateral boundaries with dissolved inorganic carbon, dissolved organic carbon, alkalinity, and iron obtained from stabilized climatological 3-D fields of the global standard configuration ORCA2 (Aumont and Bopp, 2006) and nitrate, phosphate, silicate, and dissolved oxygen 
(a) $\mathrm{NO}_{3}$ along $10^{\circ} \mathrm{W}$ : no upwelling

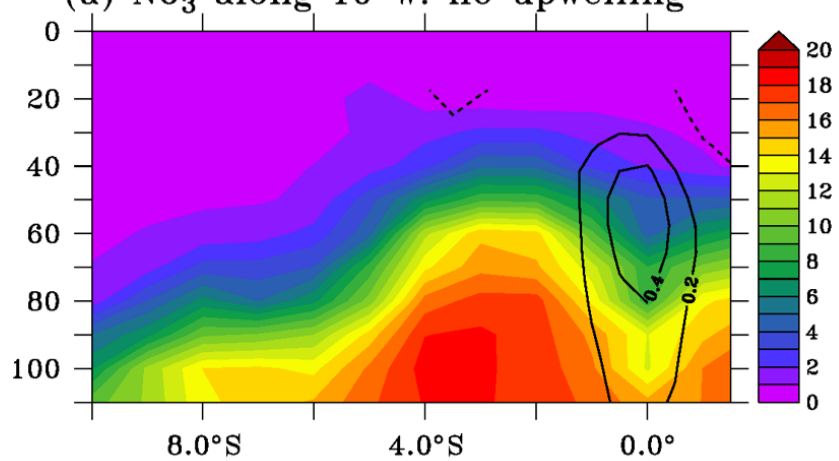

(b) Chl along $10^{\circ} \mathrm{W}$ : no upwelling

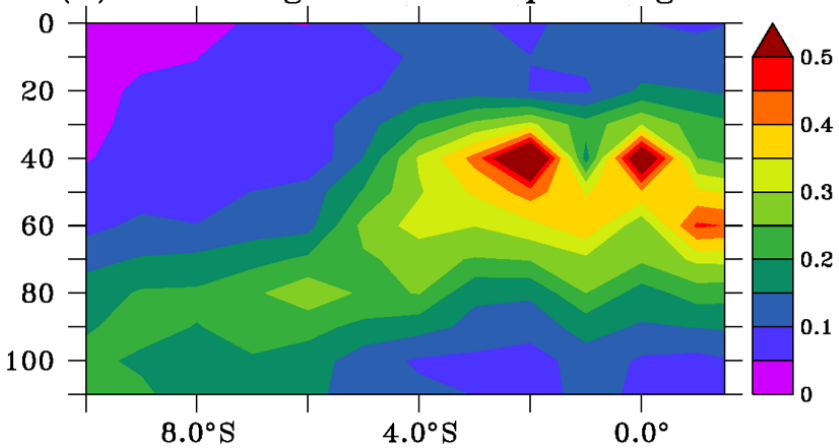

(c) $\mathrm{NO}_{3}$ along $10^{\circ} \mathrm{W}$ : upwelling

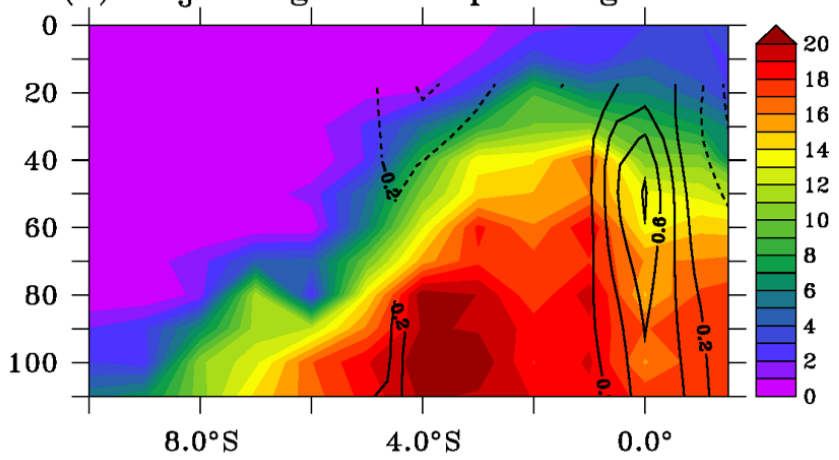

(d) $\mathrm{T}$ and $\mathrm{U}$ at $10^{\circ} \mathrm{W}, 0^{\circ} \mathrm{N}$

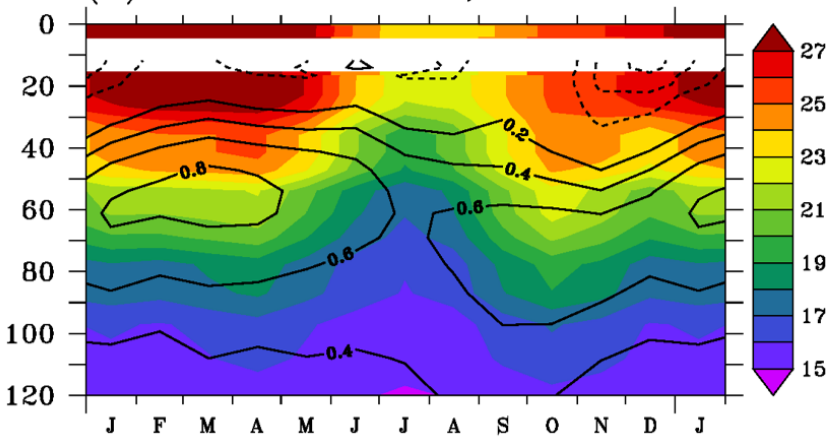

Figure 2. (a, c) Observed nitrate $\left(\mu \mathrm{molL} \mathrm{L}^{-1}\right)$ and chlorophyll $\left(\mathrm{mg} \mathrm{m}^{-3}\right.$; (b) distributions along $10^{\circ} \mathrm{W}$ during low-productivity (a, b) and high-productivity (c) conditions. Zonal velocity is overlaid on nitrate distribution. (d) Seasonal cycles of temperature (colors; ${ }^{\circ} \mathrm{C}$ ) and zonal current (contours; $\mathrm{m} \mathrm{s}^{-1}$ ) at the $0^{\circ} \mathrm{N}, 10^{\circ} \mathrm{W}$ mooring. Velocity contour interval is $0.2 \mathrm{~m} \mathrm{~s}^{-1}$; the $0 \mathrm{~m} \mathrm{~s}^{-1}$ contour has been removed.

from the World Ocean Atlas observation database (WOA; Garcia et al., 2010).

The model is integrated from 1993 to 2015 and monthly averages for the period 1995 to 2015 are analyzed. Such short spin-up is justified by the fast adjustment of the equatorial dynamics and the main focus of the study which is on the upper ocean variability.

The three-dimensional nitrate balance solved in the model reads as follows:

$$
\begin{aligned}
\frac{\partial \mathrm{NO}_{3}}{\partial t} & =-u \frac{\partial \mathrm{NO}_{3}}{\partial x}-v \frac{\partial \mathrm{NO}_{3}}{\partial y}-w \frac{\partial \mathrm{NO}_{3}}{\partial z} \\
& +D_{1}\left(\mathrm{NO}_{3}\right)+\frac{\partial}{\partial z}\left(K_{z} \frac{\partial \mathrm{NO}_{3}}{\partial z}\right)+\mathrm{SMS},
\end{aligned}
$$

in which $\mathrm{NO}_{3}$ is the model nitrate concentration, $(u, v, w)$ are the velocity components, $D_{1}\left(\mathrm{NO}_{3}\right)$ is the lateral diffusion operator, and $K_{z}$ is the vertical diffusion coefficient for tracers. The first three terms on the right-hand side are the zonal, meridional, and vertical advection; the fourth and fifth terms are the lateral and vertical diffusions. The last term, called "source minus sink" (SMS), is the nitrate change rate due to biogeochemical processes which include uptake by nanophytoplankton and diatoms, nitrification, denitrification, and nitrogen fixation. The different terms are computed online and averaged over 1-month periods.
We estimate the low- and high-frequency contributions to the advection terms by separating off-line each advection term into low-frequency and submonthly components:

$-\overline{\frac{\partial \mathrm{NO}_{3}}{\partial x}}=-\bar{u} \frac{\overline{\partial \mathrm{NO}_{3}}}{\partial x}-\overline{u^{\prime} \frac{\partial \mathrm{NO}_{3}^{\prime}}{\partial x}}$.

The left-hand-side term is the monthly average of zonal advection. On the right-hand side, the first term is the monthly zonal advection calculated from monthly averages of zonal current $(\bar{u})$ and nitrate concentrations $\left(\overline{\mathrm{NO}_{3}}\right)$. The second term is the eddy advection term. It includes all the submonthly advection contributions which, in this region, may include influences of inertia-gravity waves, mixed Rossbygravity waves, Kelvin waves, and eddies or tropical instability waves (e.g., Athié et al., 2009; Jouanno et al., 2013). It is calculated as the residual between the total and mean zonal advection. Meridional and vertical advection are decomposed in the same way. Such decomposition has been used to estimate the eddy contribution to SST budget in the Pacific mixed layer (Vialard et al., 2001) and oxygen advection in the Arabian Sea (Resplandy et al., 2012).

We use the method described in Vialard and Delecluse (1998) to investigate nitrate budgets in the mixed layer and in the euphotic layer. An entrainment term appears when in- 
tegrating Eq. (1) over a time-varying layer:

$$
\begin{aligned}
\frac{\partial\left\langle\mathrm{NO}_{3}\right\rangle}{\partial t} & =-\left\langle u \frac{\partial \mathrm{NO}_{3}}{\partial x}\right\rangle-\left\langle v \frac{\partial \mathrm{NO}_{3}}{\partial y}\right\rangle-\left\langle w \frac{\partial \mathrm{NO}_{3}}{\partial z}\right\rangle \\
& +\left\langle D_{1}\left(\mathrm{NO}_{3}\right)\right\rangle+\frac{1}{h}\left(K_{z} \frac{\partial \mathrm{NO}_{3}}{\partial z}\right)_{z=-h}+\langle\mathrm{SMS}\rangle \\
& -\frac{1}{h} \frac{\partial h}{\partial t}\left(\left\langle\mathrm{NO}_{3}\right\rangle-\mathrm{NO}_{3 z=-h}\right)
\end{aligned}
$$

where brackets indicate the vertical average over the layer depth $h$. The last term arises from time variations in the integration depth $h$. This term is often referred to as entrainment at the base of the layer (e.g., Vialard and Delecluse, 1998) and computed as a residual of the other terms of Eq. (3). Here we verified that this term is small and we choose not to show it. The mixed-layer depth is computed as the depth where the density is $0.03 \mathrm{~kg} \mathrm{~m}^{-3}$ higher than the $10 \mathrm{~m}$ density (de Boyer Montégut et al., 2004) and the depth of the euphotic layer is the depth where the surface photosynthetically available radiation (PAR) is reduced to $1 \%$ (Morel and Berthon, 1989). The contribution of lateral diffusion to the nitrate budgets in both layers is weak and is not shown.

\subsection{Evaluation of the modeled seasonal cycle}

The climatology of the simulated surface chlorophyll calculated over the same period (1998-2015) as observations (Fig. 1) is shown in Fig. 3. The model reproduces the pattern and semiannual variability of surface chlorophyll in the equatorial cold tongue. The simulated chlorophyll maximum is shifted about $5^{\circ}$ east of the chlorophyll maxima observed by satellite. The model surface chlorophyll is also slightly higher than observed east of the equatorial chlorophyll maximum.

The meridional sections of modeled nitrate and chlorophyll along $10^{\circ} \mathrm{W}$ presented in Fig. $4 \mathrm{a}-\mathrm{c}$ have been calculated using fields coincident with observed sections in Fig. 2a-c. The model properly reproduces the main features such as the nitracline uplift around $3^{\circ} \mathrm{S}$ and the lownitrate signature of the EUC (Fig. 4a, c). However, the simulated nitrate has a positive bias that can reach $5 \mu \mathrm{mol} \mathrm{L}^{-1}$ in the nitracline in the $5-2^{\circ} \mathrm{S}$ region. In the equatorial zone, the model nitrate is slightly overestimated (less than $1 \mu \mathrm{mol} \mathrm{L}{ }^{-1}$ ) above the $5 \mu \mathrm{mol} \mathrm{L}^{-1}$ nitrate isoline (which is close to the $20^{\circ} \mathrm{C}$ isotherm depth) and slightly underestimated (about $1 \mu \mathrm{mol} \mathrm{L}{ }^{-1}$ ) below. The nitrate-depleted surface layer is about $10 \mathrm{~m}$ shallower in the simulation than in the observations. In the equatorial zone, the position of the simulated DCM in the upper nitracline is in agreement with observations while its magnitude is more elevated by about $0.1 \mathrm{mg} \mathrm{m}^{-3}$ (Fig. 4b). Too high simulated chlorophyll is found up to the surface where the concentration is about $0.15 \mathrm{mg} \mathrm{m}^{-3}$ at the Equator instead of $0.1 \mathrm{mg} \mathrm{m}^{-3}$ in the observations.

Simulated profiles of temperature and zonal current coincident with available observed profiles (Fig. 2d) at the PI-
RATA mooring at $0^{\circ} \mathrm{N}, 10^{\circ} \mathrm{W}$ were used to calculate the climatology shown in Fig. 4d. The amplitude and phase of the seasonal cycles of modeled temperature and zonal current compare well, although the simulated temperature and current vertical structures are shallower than observed. The depths of the $20^{\circ} \mathrm{C}$ isotherm (Z20) and of the EUC core (ZEUC) are 12 and $16 \mathrm{~m}$ shallower than observed, respectively (Fig. 4e). However, the relative position of Z20 and ZEUC is correctly reproduced. The simulated nitrate concentration at ZEUC (not shown) is less than $2 \mu \mathrm{mol} \mathrm{L}{ }^{-1}$ in spring and rises to nearly $9 \mu \mathrm{molL}^{-1}$ in August, in agreement with observations at $4^{\circ} \mathrm{W}$ (Oudot and Morin, 1987). In the $20 \mathrm{~m}$ surface layer, the model captures the weakening of the SEC in January-February and September-October well (Okumura and Xie, 2006; Ding et al., 2009; Habasque and Herbert, 2018).

\section{The modeled nitrate seasonal cycle}

The good agreement between the observed and simulated patterns and seasonal variations in chlorophyll and nitrate makes the model a relevant tool to investigate the seasonal nitrate budget. Understanding variations in the surface productivity requires identification of processes below the mixed layer. So in this section, processes driving the seasonal variations in nitrate are presented in the mixed layer, but also down to the base of the euphotic layer. We focus on the $1.5^{\circ} \mathrm{S}-$ $0.5^{\circ} \mathrm{N}, 20-5^{\circ} \mathrm{W}$ region where the surface chlorophyll values are the largest.

\subsection{Nitrate budget in the mixed layer}

In the equatorial Atlantic, the seasonal variations in chlorophyll are thought to be primarily related to seasonal variability of the nitrate input (Voituriez and Herbland, 1977; Loukos and Mémery, 1999). This is illustrated well by the seasonal cycle of nitrate built from 21 years of simulation (1995-2015) in Fig. 5a, which closely matches the seasonal variability of the model (Fig. 3b) and satellite chlorophyll (Fig. 1a).

The mixed-layer nitrate concentration at the Equator shows large and coherent variations between $30^{\circ} \mathrm{W}$ and $0^{\circ} \mathrm{E}$ (Fig. 5a). This central equatorial variability does not seem to be directly connected with mixed-layer nitrate input along the African coast, in agreement with the chlorophyll behavior in the equatorial Atlantic deduced from satellite data (Grodsky et al., 2008). Four phases emerge from the nitrate seasonal evolution in the mixed layer of the central equatorial Atlantic: a nitrate increase between April and July, a decrease between August and October, a rapid increase in November, and a secondary decrease starting in December (Fig. 5b). This temporal pattern results from the imbalance between physical processes (Fig. $5 \mathrm{~h}$ ) that brings nitrate into the mixed layer and nitrate uptake by the biological activity 

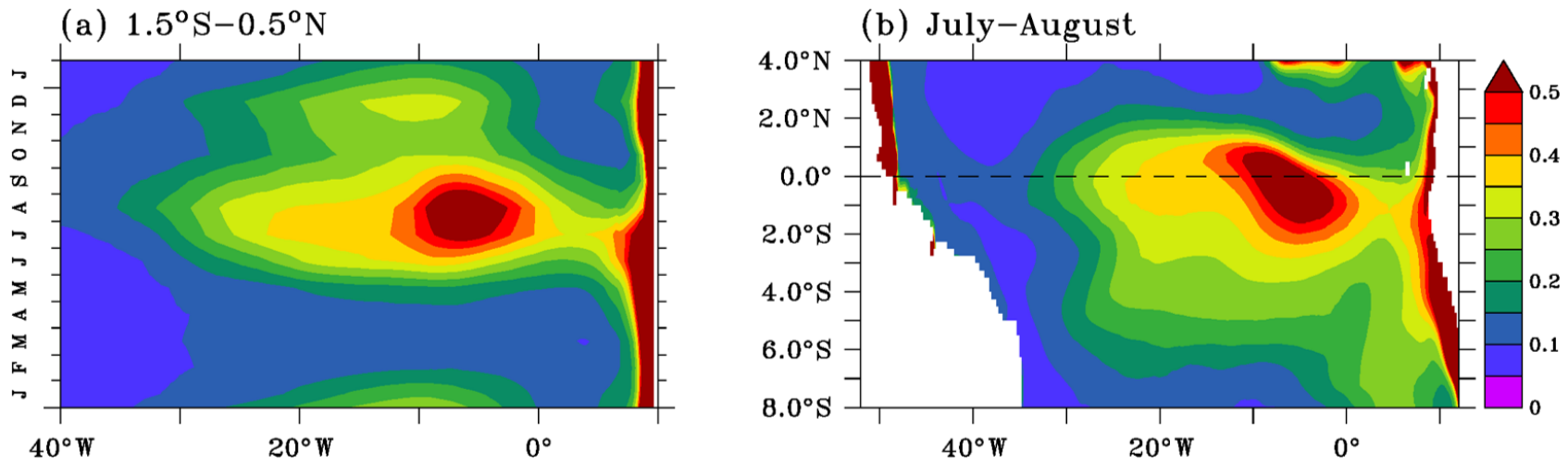

Figure 3. Seasonal cycle averaged in the upwelling region (a) and mean distribution in July-August (b) of simulated surface chlorophyll $\left(\mathrm{mg} \mathrm{m}^{-3}\right)$. Data were averaged between $1.5^{\circ} \mathrm{S}$ and $0.5^{\circ} \mathrm{N}$ in (a). The climatology is calculated over 1998-2015.

(Fig. 5g). Unlike the negligible contribution of vertical advection in the temperature budget in the mixed layer of the equatorial Atlantic (Jouanno et al., 2011b), both vertical advection (Fig. 5e) and vertical diffusion (Fig. 5f) contribute to nitrate inputs in the mixed layer. Variations in zonal advection drive variations in horizontal advection (Fig. 5c, d) that acts to bring some low-nitrate water to the cold tongue area during most of the year. The main peak occurs in JulyAugust and a secondary peak occurs in December. Horizontal advection is close to zero in February-May.

In Fig. 6, we show the regional distribution of the different terms of the nitrate balance in July, when the nitrate supply to the mixed layer by physical processes and nitrate uptake are at their maximum. During this period, the biological sink is not efficient enough to offset the physical supply and the surface nitrate (Fig. 6a) shows a maximum between $1.5^{\circ} \mathrm{S}$ and $0.5^{\circ} \mathrm{N}$ from 20 to $5^{\circ} \mathrm{W}$ at the location of maximum vertical input through advection (Fig. 6e) and diffusion (Fig. 6f) and biological sink (Fig. 6g). Advection of nitratepoor water from the east (Fig. 6c) and meridional advection (Fig. 6d) slightly counteract the vertical nitrate supply near the Equator. Off the Equator, meridional advection acts to spread the upwelled nitrate-rich water poleward along the northern boundary of the nitrate-rich patch and, to a lesser extent, along the southern boundary where the nitrate gradient is weaker. This may contribute to the meridional extension of the observed (Fig. 1b) and model (Fig. 3a) chlorophyll distribution.

The scenario leading to the December secondary nitrate maximum in the mixed layer is close to the boreal summer nitrate evolution, except that the duration of the processes is shorter (about 1 month long), their magnitudes are weaker, and they span a narrower longitudinal range (Fig. 5). Between the summer and December nitrate maxima, vertical processes strongly decrease (Fig. 5c, f) and sustain less nitrate supply in the mixed layer, allowing the biological sink (Fig. $5 \mathrm{~g}$ ) to prevail over the physical input (Fig. 5h).

\subsection{Nitrate budget in the euphotic layer}

In this section, we examine how, in addition to processes in the mixed layer, variations in nitrate below the mixed-layer impact variations in surface nitrate and, in turn, chlorophyll. Also, variations in the euphotic layer where the biological production takes place allow better explanation of the transition between the low- and high-productivity seasons. The seasonal cycles of chlorophyll, nitrate, and the main processes involved in nitrate change in the $1.5^{\circ} \mathrm{S}-0.5^{\circ} \mathrm{N}, 20$ $5^{\circ} \mathrm{W}$ region from the surface to $80 \mathrm{~m}$ are shown in Fig. 7 . Depths of the mixed layer, of the euphotic layer, and of the EUC core are overlaid. The depth of the thermocline core is represented by the $20^{\circ} \mathrm{C}$ isotherm depth. The separated low-frequency and submonthly contributions to the advection terms are presented in Fig. 8.

The semiannual cycle of chlorophyll described in the mixed layer is also visible in the entire euphotic layer (Fig. 7a). The seasonal cycle of the depth of the simulated DCM is in agreement with observations (Monger et al., 1997). It is located near the thermocline core between 50 and $60 \mathrm{~m}$ in spring, rises toward the surface at the same time as the thermocline core in summer, sinks in early fall, and rises again in November. In February-April, chlorophyll values are low in the nitrate-depleted surface layer as in oligotrophic ecosystems. The semiannual variations in chlorophyll in the euphotic layer are closely associated with semiannual variations in nitrate (Fig. 7b).

The nitrate change rate is at a maximum at the base of the euphotic layer near the EUC core (Fig. 7c). Its semiannual cycle can be seen as an interplay between the physical supply (Fig. 7i) and the biological sink (Fig. 7h). Physical processes mostly bring nitrate into the euphotic layer with maximum input in the mixed layer in May-August and below the mixed layer in November. In contrast, nitrate is consumed by the biological activity in the euphotic layer and remineralized below. Physical supply is stronger than biological loss during the main peak of the nitrate change rate in May-July and 
(a) No upwelling modeled $\mathrm{NO}_{3}$

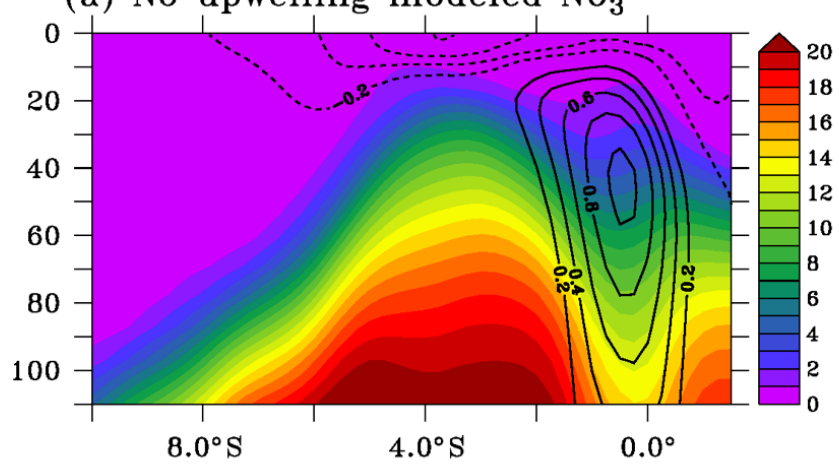

(b) No upwelling modeled chl

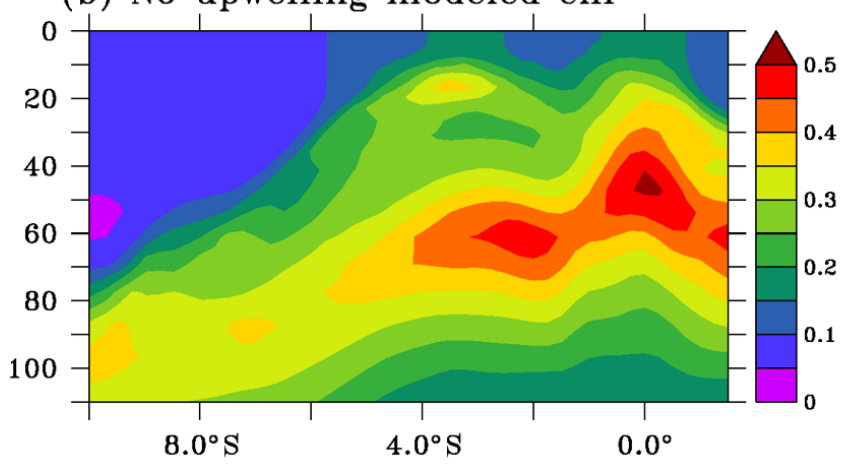

(c) Upwelling modeled $\mathrm{NO}_{3}$

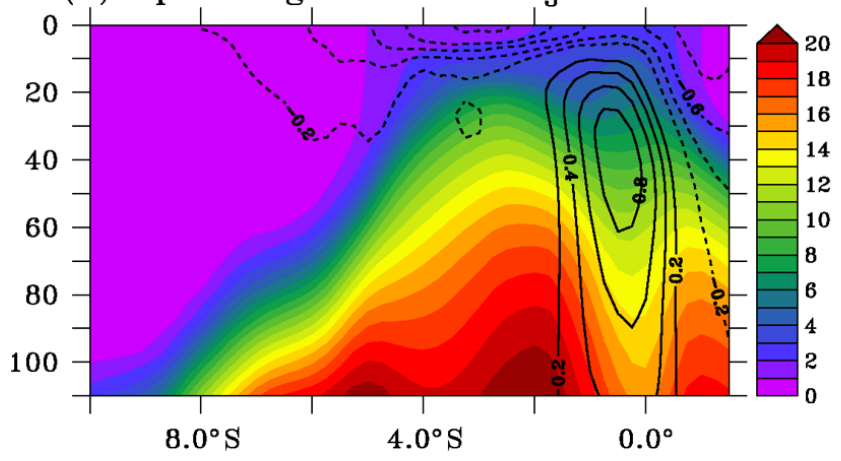

(d) $\mathrm{T}$ and $\mathrm{U}$ at $10^{\circ} \mathrm{W}, 0^{\circ}$

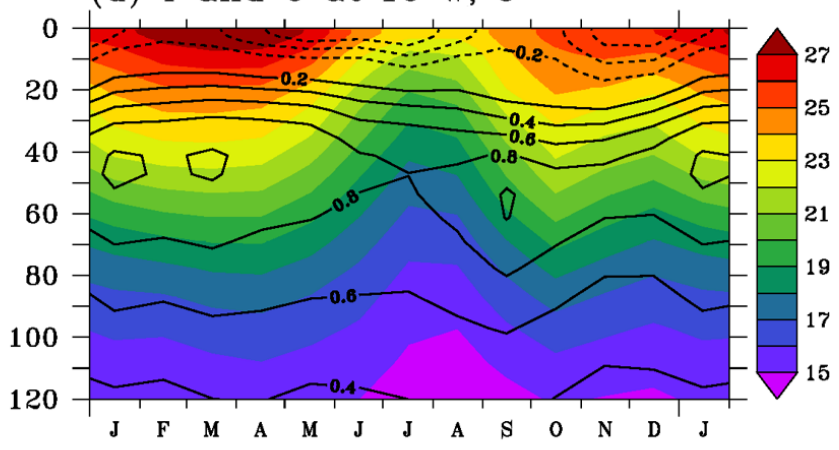

(e) $\mathrm{Z}_{20}$ and $\mathrm{Z}_{\mathrm{EUC}}$

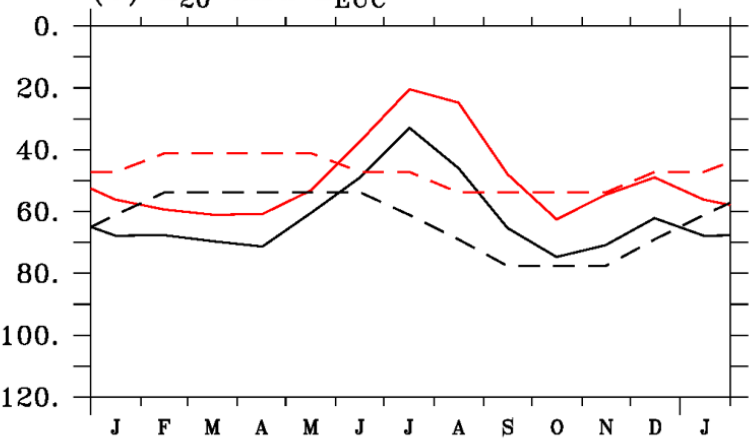

Figure 4. (a, c) Simulated nitrate $\left(\mu \mathrm{mol} \mathrm{L}^{-1}\right)$ and chlorophyll $\left(\mathrm{mg} \mathrm{m}^{-3} ; \mathbf{b}\right)$ distributions along $10^{\circ} \mathrm{W}$ during low-productivity $(\mathbf{a}, \mathbf{b})$ and high-productivity (c) conditions. Zonal velocity is overlaid on nitrate distribution. (d) Seasonal cycles of temperature (colors; $\left.{ }^{\circ} \mathrm{C}\right)$ and zonal current (contours; $\mathrm{m} \mathrm{s}^{-1}$ ) at $0^{\circ} \mathrm{N}, 10^{\circ} \mathrm{W}$. Velocity contour interval is $0.2 \mathrm{~m} \mathrm{~s}^{-1}$; the $0 \mathrm{~m} \mathrm{~s}^{-1}$ contour has been removed. (e) Observed (black) and simulated (red) depths of the $20^{\circ} \mathrm{C}$ isotherm (full line) and of the EUC core (dashed line) at $0^{\circ} \mathrm{N}, 10^{\circ} \mathrm{W}$.

during the short second peak in November; biological losses prevail over the physical supply in August-October and in December-January. The nitrate supply in November suggests that the observed and simulated elevated chlorophyll values in December result from a second chlorophyll bloom and not from a persistence of elevated nitrate and chlorophyll concentrations following the summer bloom (Hisard, 1973; Oudot and Morin, 1987).

Vertical advection always brings nitrate into the euphotic layer (Fig. 7f). It drives the main nitrate increase in MayJuly and the secondary one in November when easterly winds strengthen. The maximum vertical advection is located near the layer of maximum vertical nitrate gradient, close to the depth of the $20^{\circ} \mathrm{C}$ isotherm, and it occurs when the vertical velocity is strong (July and November). Vertical advection of nitrate-rich water at the base of the mixed layer favors the intensified vertical diffusion in summer and NovemberDecember (Fig. $7 \mathrm{~g}$ ), with an acceleration of the SEC which increases the vertical shear with the EUC and, in turn, increases the vertical mixing in the mixed layer (Jouanno et al., 2011b). Both the low-frequency (Fig. 8c) and eddy (Fig. 8f) advection contribute to the nitrate supply through vertical ad- 


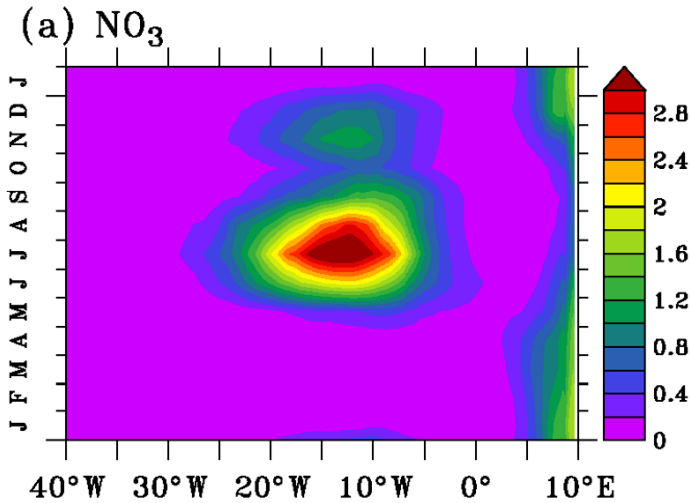

(b) $\mathrm{NO}_{3}$ change rate

(c) Zonal advection
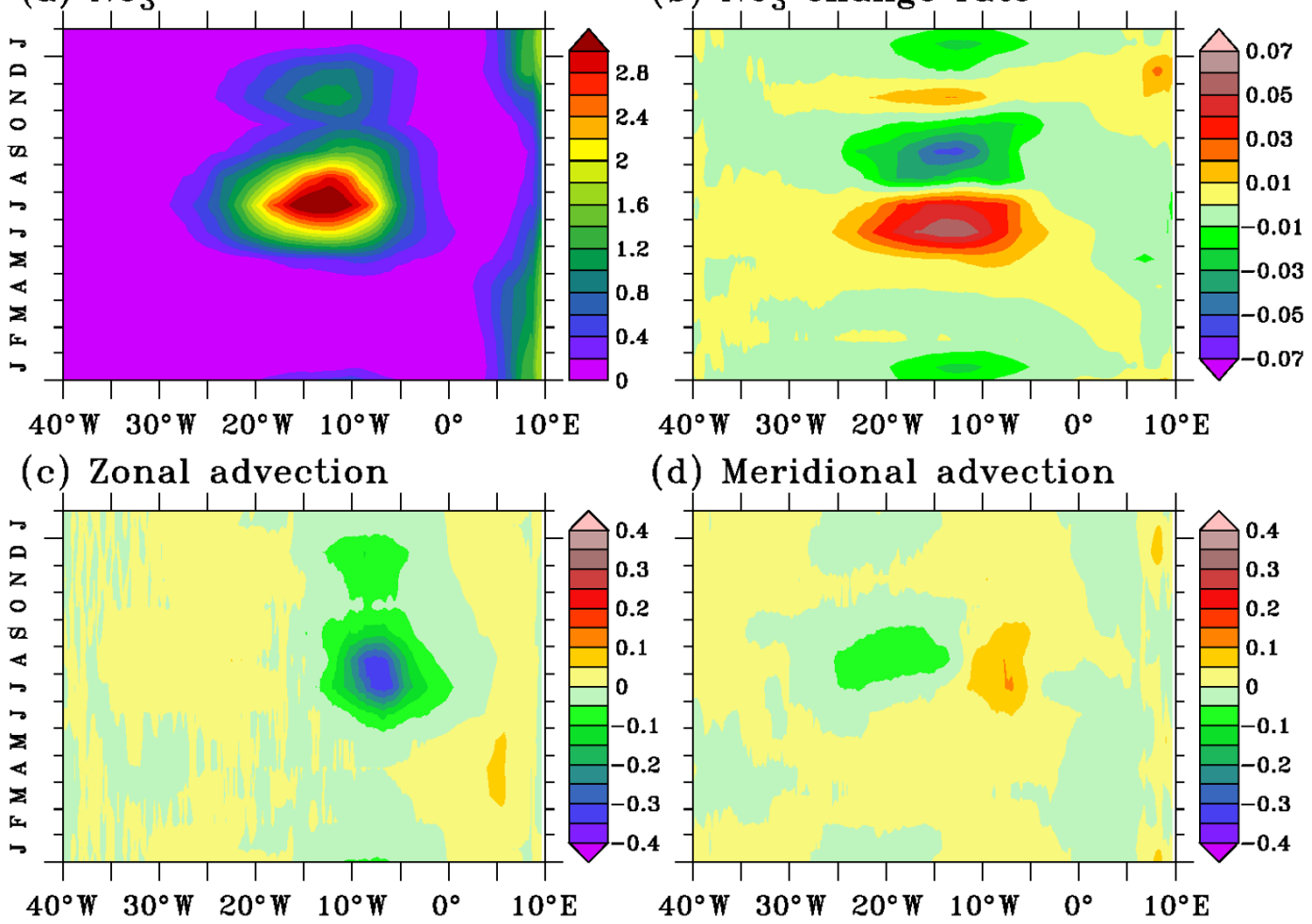

(d) Meridional advection

(e) Vertical advection
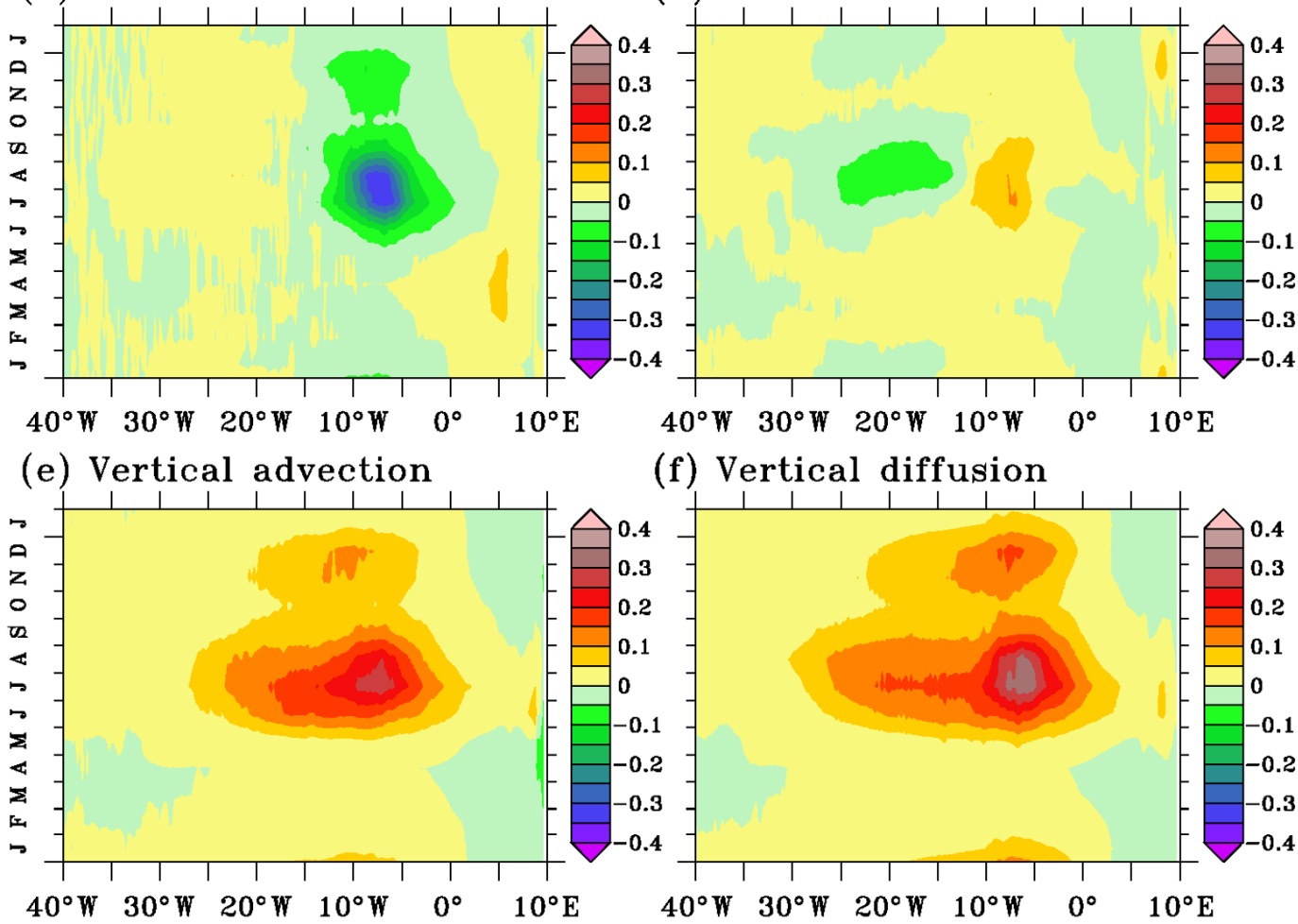

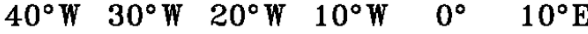

(f) Vertical diffusion

(g) $\mathrm{NO}_{3} \mathrm{SMS}$
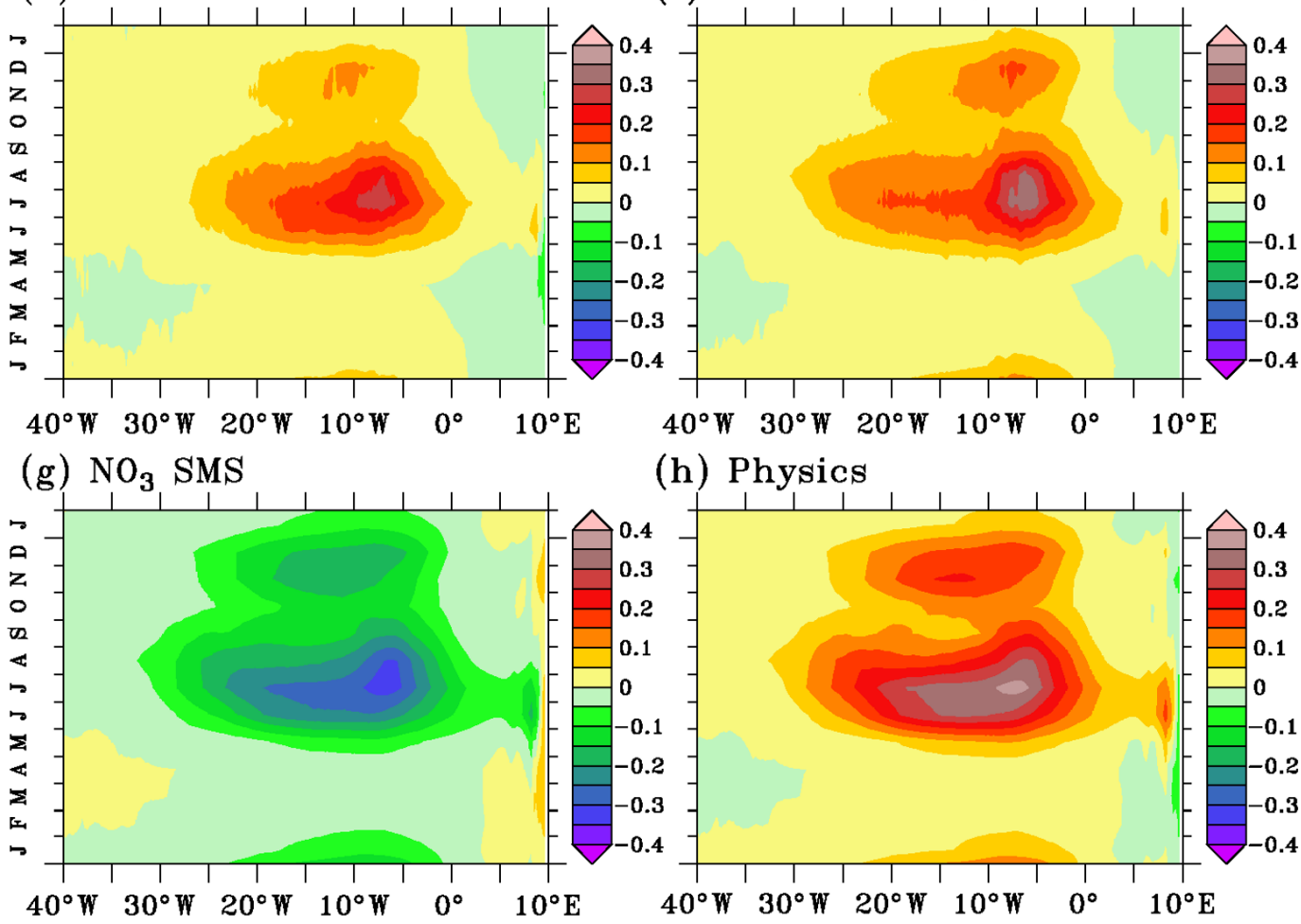

(h) Physics

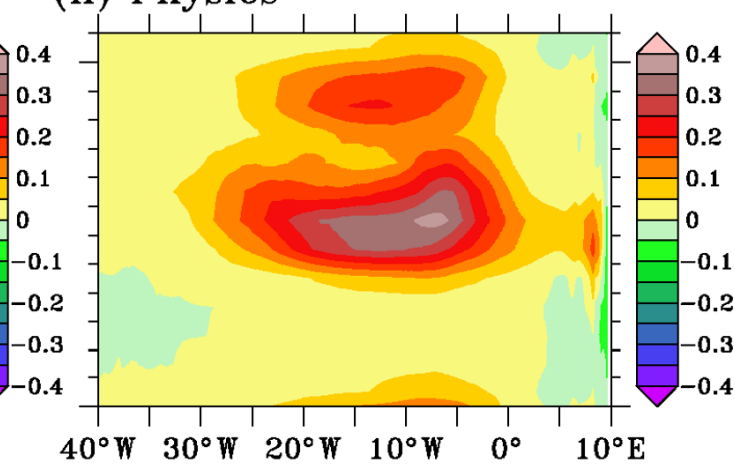

Figure 5. Seasonal cycle of modeled (a) surface nitrate $\left(\mu \mathrm{mol} \mathrm{L}^{-1}\right)$, (b) nitrate change rate, (c) zonal advection, (d) meridional advection, (e) vertical advection, (f) vertical diffusion, (g) nitrate source minus sink, and (h) physical processes averaged in $1.5^{\circ} \mathrm{S}-0.5^{\circ} \mathrm{N}$ in the mixed layer. Tendency units are micromoles per liter per day. Note that the color scale of nitrate change rate is different from the color scale of other tendencies. Climatology has been calculated between 1995 and 2015. 
(a) $\mathrm{NO}_{3}$ and current

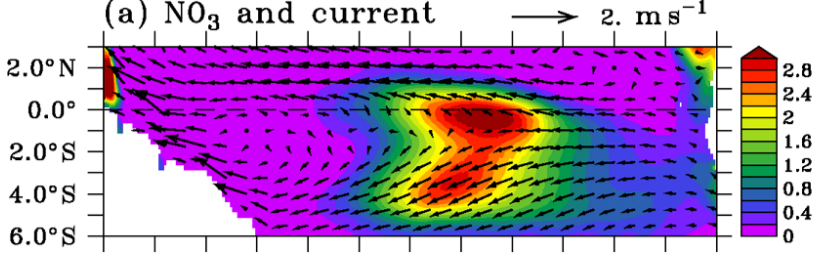

(c) Zonal advection

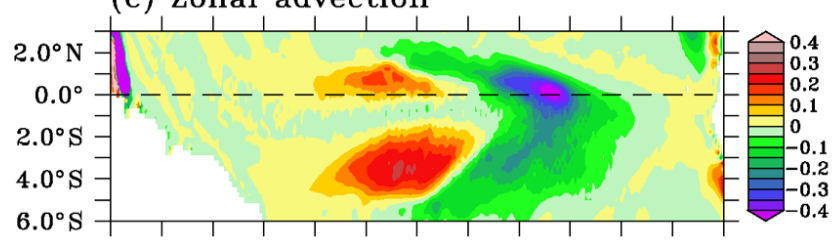

(e) Vertical advection

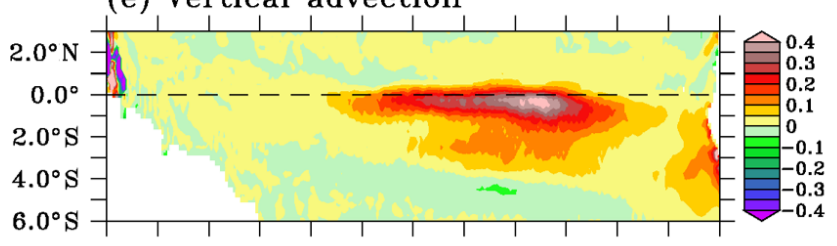

(g) $\mathrm{NO}_{3} \mathrm{SMS}$

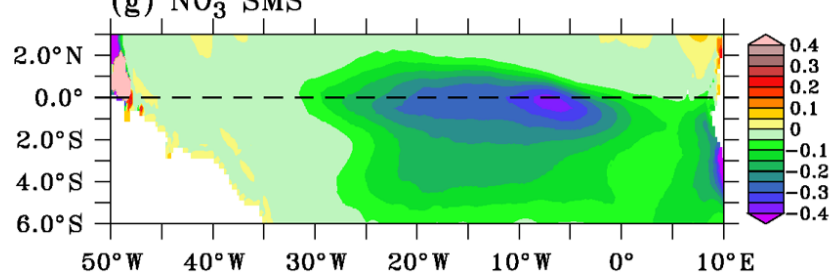

(b) $\mathrm{NO}_{3}$ change rate

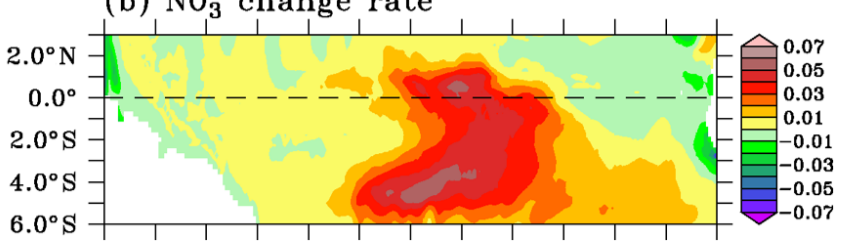

(d) Meridional advection

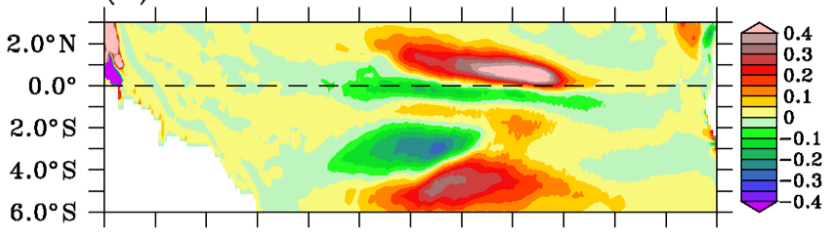

(f) Vertical diffusion

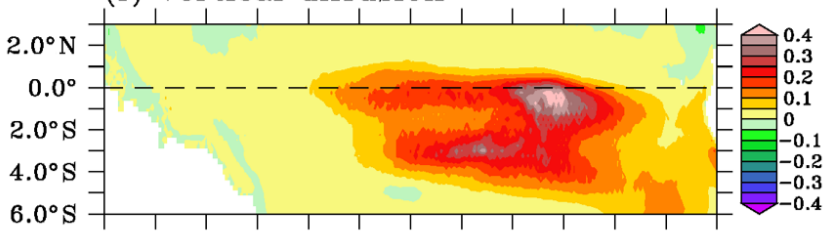

(h) Physics

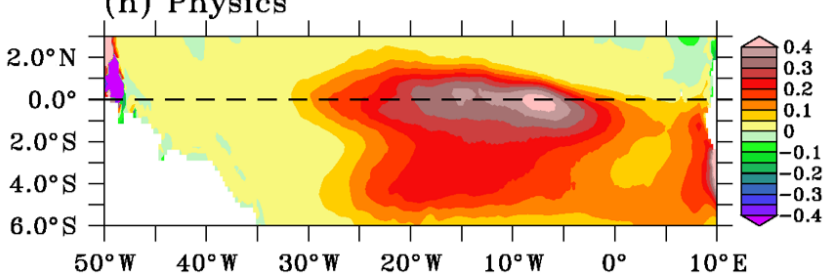

Figure 6. Maps of (a) nitrate, (b) nitrate change rate, (c) zonal advection, (d) meridional advection, (e) vertical advection, (f) vertical diffusion, (g) nitrate source minus sink, and (h) physical processes averaged in the mixed layer in July. The mean current in the mixed layer is superimposed in (a). Note that color scale in (b) is different from the color scale in (c)-(h). Nitrate units are micromoles per liter and tendency units are micromoles per liter per day.

vection, especially in the upper EUC between June and December. The eddy advection is more sustained than the lowfrequency advection.

Below the mixed layer, horizontal advection (Fig. 7d, e) removes nitrate all year long. It drives the strong nitrate loss in August-September and the lesser nitrate loss in December-January (Fig. 7c) when the contributions of both zonal (Fig. 7d) and meridional (Fig. 7e) advection are the largest. The contribution of the low-frequency zonal advection (Fig. 8a) compares to that of the eddy advection (Fig. 8d) while the eddy signal (Fig. 8e) controls the meridional advection. Negative low-frequency zonal and meridional advection indicate the transport of low-nitrate water from the west by the EUC and from the north by the low-frequency southward component of the subsurface current (Perez et al., 2014). In the mixed layer, zonal advection acts to decrease the nitrate concentration, and meridional advection is a weak source of nitrate. The low-frequency advection of nitrate poor water from the east is the largest where the zonal nitrate gradient is the strongest. The low-frequency meridional advec- tion (Fig. 8b) reveals the influence of the equatorial cell: the northward transport of nitrate-rich upwelled water dominates the meridional advection in the mixed layer on average in the $1.5^{\circ} \mathrm{S}-0.5^{\circ} \mathrm{N}, 20-5^{\circ} \mathrm{W}$ region.

\section{Discussion}

Observations and the model used in this study show semiannual cycles of chlorophyll and nitrate. The model further shows that they are sustained by semiannual variations in processes in the euphotic layer. Changes of nitrate properties in the EUC and intraseasonal processes are involved in shaping the seasonal cycle of nitrate supply and losses.

\subsection{Variability of nitrate in the Equatorial Undercurrent}

Upwelled water in the central basin originates in the upper part of the EUC (Fig. 7f). The EUC waters mainly originate in the very oligotrophic ecosystem of the south sub- 
(a) $\mathrm{Chl}$

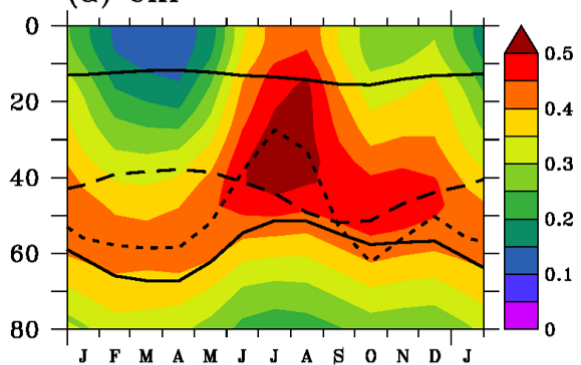

(d) Zonal advection

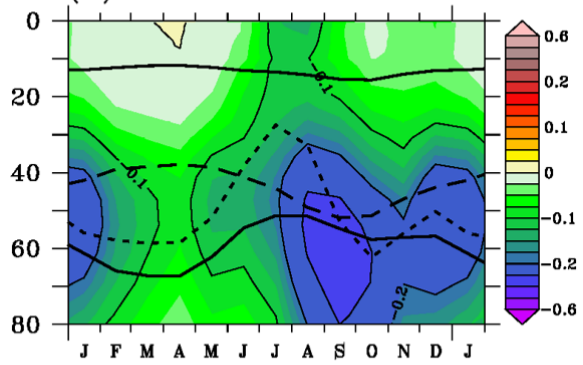

(g) Vertical diffusion

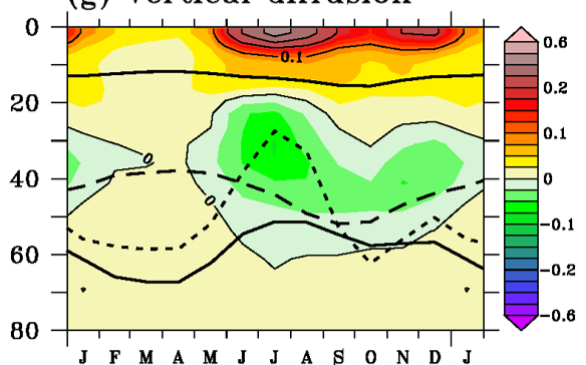

(b) $\mathrm{NO}_{3}$

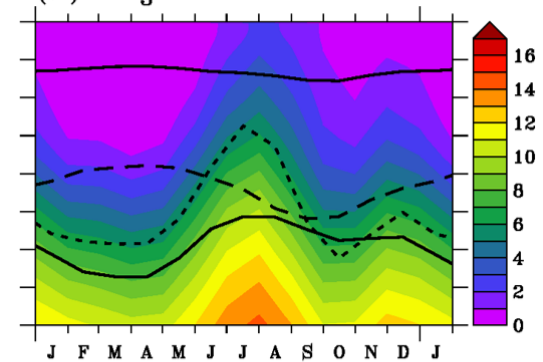

(e) Meridional advection

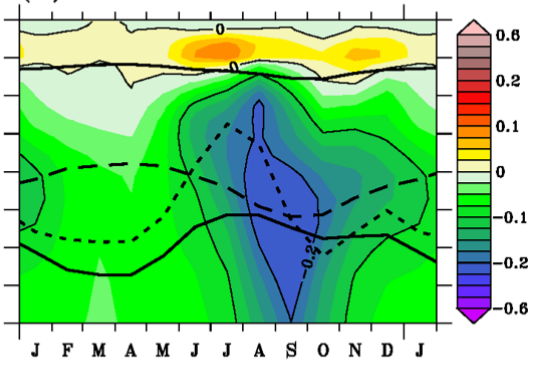

(h) $\mathrm{NO}_{3} \mathrm{SMS}$

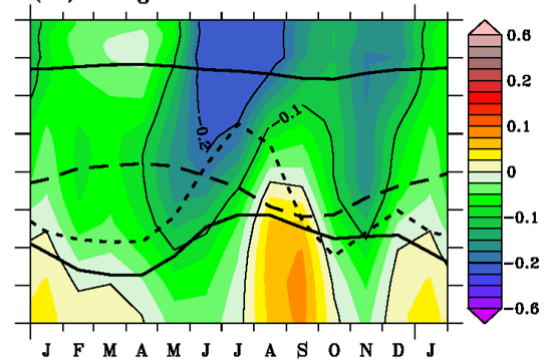

(c) $\mathrm{NO}_{3}$ change rate

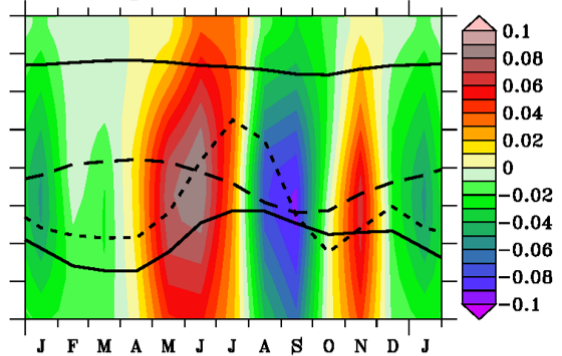

(f) Vertical advection

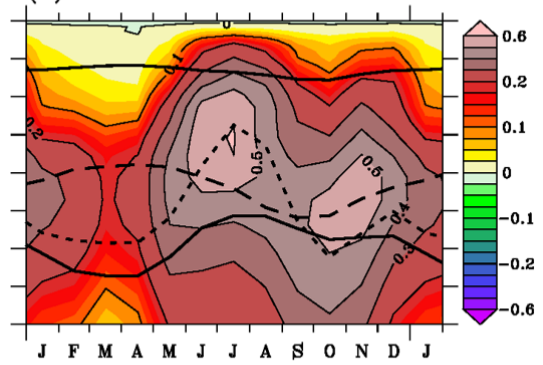

(i) Physics

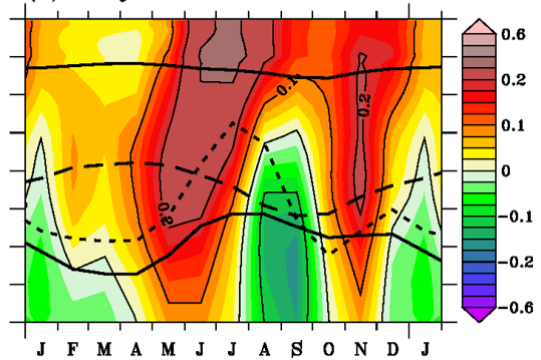

Figure 7. Seasonal cycle of vertical profiles of (a) chlorophyll, (b) nitrate, (c) nitrate change rate, (d) zonal advection, (e) meridional advection, (f) vertical advection, (g) vertical diffusion, (h) nitrate source minus sink, and (i) physical processes averaged in $1.5^{\circ} \mathrm{S}-0.5^{\circ} \mathrm{N}$, $20-5^{\circ} \mathrm{W}$. Chlorophyll units are milligrams per cubic meter, nitrate units are micromoles per liter, and tendency units are micromoles per liter per day. Tendency contours are every $0.1 \mu \mathrm{molL}^{-1} \mathrm{~d}^{-1}$. The depths of the mixed layer (upper solid line), of the euphotic layer (lower solid line), of the EUC core (dashed line), and of the $20^{\circ} \mathrm{C}$ isotherm (dotted line) are indicated. Note that color scale in (c) is different from the color scale in (d)-(i).

tropical gyre (Oudot, 1983; Blanke et al., 2002; Hazeleger et al., 2003; Aiken et al., 2017). Waters are transported westward, feed the North Brazil Undercurrent (NBUC), and are entrained within the North Brazil Current retroflection before entering the EUC. A small fraction of water also originates in the North Equatorial Current (Bourlès et al., 1999; Hazeleger et al., 2003). Therefore, this may explain that water transported eastward by the EUC has relatively low nitrate concentrations compared to nearby north and south water masses (Fig. 3a, c) in agreement with in situ measurements (Oudot, 1983). This relatively low-nitrate water is upwelled toward the surface layer along the Equator.

Seasonal changes of the nitrate concentration in the EUC in the central equatorial basin are closely related to the seasonal nitracline shoaling (Oudot and Morin, 1987). The semiannual cycle of the nitracline depth follows the basin-wide adjustment of the thermocline to the wind forcing via in- teractions between wind-forced Kelvin waves and boundaryreflected Rossby waves (Merle, 1980; Ding et al., 2009). This adjustment conditions the depth of the thermocline and associated nitracline that varies from $60 \mathrm{~m}$ in spring to about $20 \mathrm{~m}$ in July-August while the upwelling core remains in the upper part of the EUC, at 20-30 m, all year long (Fig. 4e). The smallest vertical supply (Fig. 7f) occurs when the nitracline is well below the weak upwelling core in spring. In MayJuly and November, the vertical velocity is strong and the nitracline gets closer to the upwelling core, allowing vertical advection to increase.

The annual shoaling of the thermocline in the western basin associated with the semiannual shoaling in the central basin leads to a strong zonal slope of the thermocline depth in July-September and December-January (Ding et al., 2009) and also of the nitracline. During these periods of time, the resulting strongly negative zonal advection (Fig. 7d) 
(a) LF zonal advection

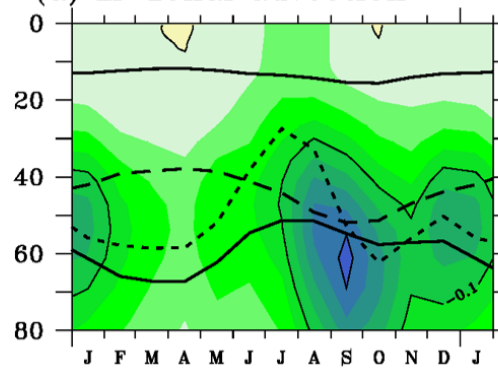

(d) Eddy zonal advection

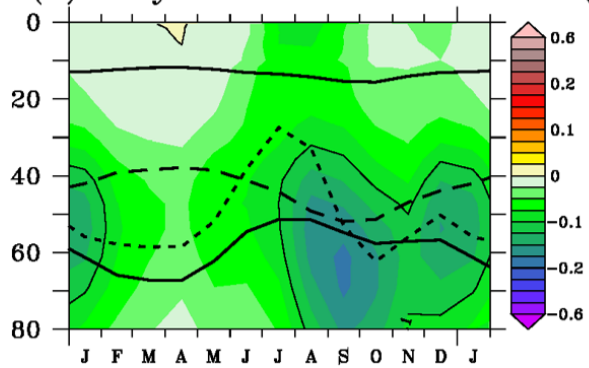

(b) LF meridional advection

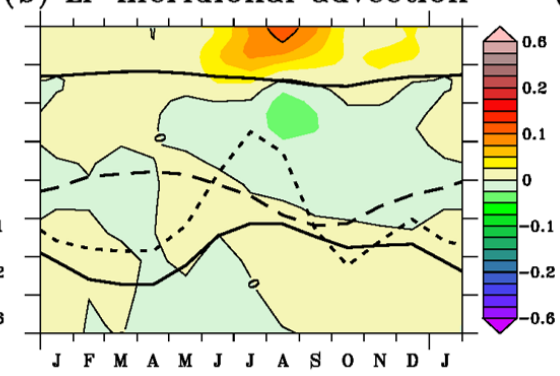

(e) Eddy meridional advection

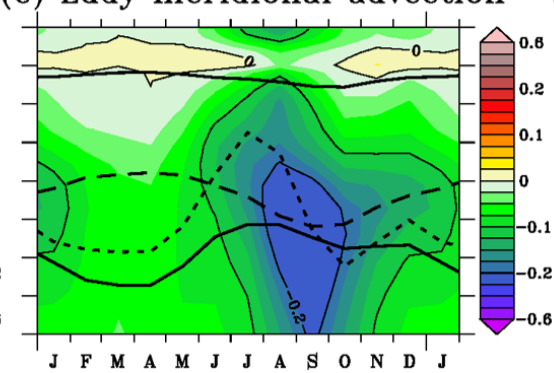

(c) LF vertical advection

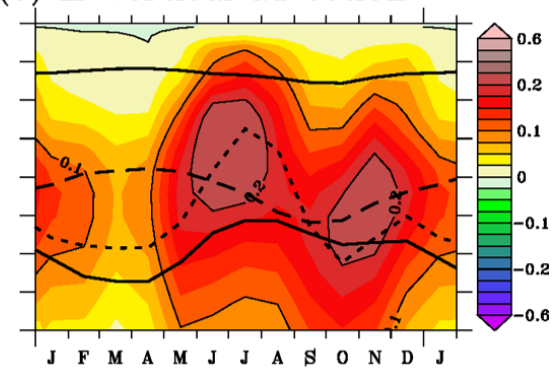

(f) Eddy vertical advection

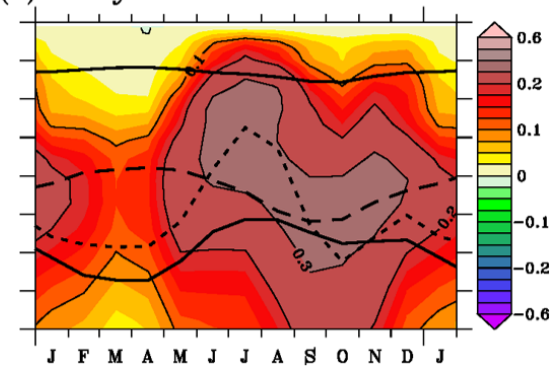

Figure 8. Seasonal cycle of vertical profiles of low-frequency (LF; a, b, c) and eddy (d, e, f) zonal advection (a, d), meridional advection (b, e), and vertical advection (c, f). Tendency contours are every $0.1 \mu \mathrm{molL} \mathrm{L}^{-1} \mathrm{~d}^{-1}$. The depths of the mixed layer (upper solid line), of the euphotic layer (lower solid line), of the EUC core (dashed line), and of the $20^{\circ} \mathrm{C}$ isotherm (dotted line) are indicated.

in the EUC underlines the efficiency of the EUC in reducing the local nitrate concentrations. Nitrate removal by zonal advection in the EUC contributes to decrease the vertical nitrate gradient, which, associated with a reduced vertical velocity, leads to moderate vertical nitrate supply in AugustSeptember. At that time of the year, physical processes drive reduced nitrate supply in the upper part of the euphotic layer and nitrate removal in its deeper part (Fig. 7i).

The seasonal nitrate supply in the center of the equatorial Atlantic is supported by vertical processes and strongly modulated by losses through horizontal advection in the EUC linked to the semiannual thermocline uplift of the nitracline. Variations in the nitrate concentration in the source waters of the NBUC may be another driver of nitrate variations in the EUC as suggested by White (2015), who finds that variations in temperature in the NBUC contribute to variations in the cold tongue SST 6 to 8 months later. Changes along the EUC pathway (meridional circulation in the tropical cells, elevation of the nitracline in the west, intraseasonal processes) may also impact horizontal and vertical nitrate gradient and the rates of supply and removal of nitrate in the central equatorial Atlantic. This deserves further attention.

\subsection{Intraseasonal processes}

On average in the $1.5^{\circ} \mathrm{S}-0.5^{\circ} \mathrm{N}, 20-5^{\circ} \mathrm{W}$ region, our model results show that horizontal eddy advection is responsible for nitrate decrease, especially in August-September, and that vertical eddy advection supplies the euphotic layer with nitrate. The intraseasonal nitrate variations may have the same origins as temperature modulations observed at periods between 10 and $50 \mathrm{~d}$ in the cold tongue (Marin et al., 2009; de Coëtlogon et al., 2010; Jouanno et al., 2013; Herbert and Bourlès, 2018). TIWs are observed west of $10^{\circ} \mathrm{W}$ at periods between 20 and $50 \mathrm{~d}$ (Jochum et al., 2004; Athié and Marin, 2008; Jouanno et al., 2013). They are active in boreal summer, decrease in fall, emerge again at the end of the year with lesser intensity than in summer, and disappear in spring (Jochum et al., 2004; Caltabiano et al., 2005; Perez et al., 2019). East of $10^{\circ} \mathrm{E}$, the impacts of wind-forced equatorial waves superimpose at different frequencies (Houghton and Colin, 1987; Athié et al., 2008; de Coëtlogon et al., 2010; Jouanno et al., 2013; Herbert and Bourlès, 2018): Kelvin waves at periods between 25 and $40 \mathrm{~d}$, mixed Rossby-gravity waves between 15 and $20 \mathrm{~d}$, and inertia-gravity waves between 5 and $11 \mathrm{~d}$.

Considering the upper $20 \mathrm{~m}$ in the equatorial Atlantic, Jochum et al. (2004) found that the annual meridional advective heat flux associated with TIWs was nearly offset by the vertical advective heat flux. In contrast, Peter et al. (2006) attributed the warming in the mixed layer induced by eddy horizontal advection between 30 and $5^{\circ} \mathrm{W}$ to TIWs because of strong southward heat transport. In the Pacific Ocean, the compensation between the TIW horizontal and vertical heat advection in the mixed layer was also suggested by Vialard et al. (2001). However, Menkes et al. (2006) found that the vertical advection associated with TIWs was low and their effect was to warm the Pacific cold tongue in the upper 200 m. Mixed Rossby-gravity waves, inertia-gravity waves, 
and Kelvin waves are believed to contribute to cooling the Atlantic cold tongue through both northward advection of cold tongue water and vertical mixing (Houghton and Colin, 1987; Marin et al., 2009; Jouanno et al., 2013), although no calculations of the heat budget were done.

The coincidence of high chlorophyll concentrations with meridional oscillations of currents associated with an anticyclonic eddy observed during a summer cruise in the equatorial Atlantic (Morlière et al., 1994) strongly suggests that TIWs may also influence ecosystems. This was further settled with synoptic observations of physical (temperature, salinity, current) and ecosystem (nitrate, chlorophyll, zooplankton, micronekton) tracers in a tropical instability vortex (Menkes et al., 2002): their horizontal and vertical structures were highly coherent. As for the heat budget, the impact of TIWs on biological production is debated, at least in the equatorial Pacific Ocean. Gorgues et al. (2005) show that the effect of TIWs is to lower the chlorophyll concentration near the Equator, because the iron loss through horizontal advection exceeds iron supply by vertical advection while Strutton et al. (2001) show that chlorophyll increases because of enhanced upwelling. As far as we know, no study shows the possible impact of TIWs and other intraseasonal waves on nitrate budget in the Atlantic Ocean.

The more elevated surface chlorophyll concentrations are found in the $1.5^{\circ} \mathrm{S}-0.5^{\circ} \mathrm{N}, 20-5^{\circ} \mathrm{W}$ zone which is affected by TIWs and Kelvin waves in the $20-50 \mathrm{~d}$ period range and by mixed Rossby-gravity and inertia-gravity waves at higher frequency. In this study, a 1-month threshold separates the eddy signal from the low-frequency signal. So, the impacts of mixed Rossby-gravity and inertia-gravity waves and part of the variability associated with TIWs and Kelvin waves at periods shorter than 1 month enter the eddy advection terms. The part of the TIW and Kelvin wave signal with longer periods is included in the low-frequency advection terms.

Several intraseasonal processes should contribute to the seasonal nitrate loss through eddy horizontal advection and nitrate input through eddy vertical advection in the mixed layer and in the euphotic layer in the $1.5^{\circ} \mathrm{S}-0.5^{\circ} \mathrm{N}, 20-5^{\circ} \mathrm{W}$ region. In this simulation, nitrate loss in the mixed layer west of $10^{\circ} \mathrm{W}$ is driven by eddy meridional advection and by eddy zonal advection to a lesser extent (not shown). As the horizontal and vertical patterns of temperature and nitrate in a tropical instability vortex are close (Menkes et al., 2002), the advection of nitrate anomaly by eddy zonal and meridional currents could drive nitrate losses by eddy zonal and meridional advection in the same way as the advection of anomalous temperature by anomalous currents drives a mixed-layer warming close to the Equator. By analogy with TIW-induced warming (Vialard et al., 2001; Peter et al., 2006; Menkes et al., 2006), TIWs could be a strong contributor to the nitrate eddy term. Nitrate loss by eddy horizontal advection is also consistent with iron loss associated with TIWs in the equatorial Pacific (Gorgues et al., 2005). East of $10^{\circ} \mathrm{W}$, the nitrate removal through eddy horizontal advection is driven by eddy zonal advection while eddy meridional advection strongly decreases (not shown). Drawing again an analogy between temperature and nitrate, the nitrate decrease through zonal advection could be attributed to Kelvin waves. In contrast, no nitrate increase through meridional advection is simulated as would be expected from mixed Rossby-gravity, inertiagravity, and Kelvin waves that cool the mixed layer. The conclusion on the nature of intraseasonal processes that affect the nitrate budget east of $10^{\circ} \mathrm{W}$ is not straightforward. One reason could be that the low-frequency signal captures part of the Kelvin-wave-induced variability as there is no sharp cutoff at $30 \mathrm{~d}$ in the spectrum of Kelvin waves (Athié and Marin, 2008; Athié et al., 2009; Jouanno et al., 2013). Another reason would be related to the different distribution of temperature and nitrate in the mixed layer because the nitrate concentration rapidly drops to zero east of $10^{\circ} \mathrm{W}$ while a temperature gradient persists in this simulation.

On an annual average, nitrate is supplied by intraseasonal advection because eddy-induced vertical advection exceeds horizontal advection. It represents a significant contribution to the nitrate budget in the central equatorial Atlantic: about $35 \%$ of the advective nitrate input in the mixed layer and about $45 \%$ in the euphotic layer. It differs from the overall warming contribution of TIWs to the SST budget of the equatorial Pacific cold tongue showed by Menkes et al. (2006). This warming contribution reflects the impact of horizontal advection as TIW-induced vertical advection is negligible. As far as horizontal eddy advection is concerned, the warming effect of zonal and meridional advection in the Pacific is consistent with the nitrate removal by zonal and meridional advection in the Atlantic.

This simulation was initially designed to study the largescale processes and it does not allow conclusions about the role of the different intraseasonal processes. However, our results strongly suggest that large-scale processes cannot totally explain the seasonal evolution of the nitrate budget. Previous studies (e.g., Athié et al., 2009; Jouanno et al., 2013) show that this model reproduces the level of energy of the TIWs and their equatorial signature in terms of sea surface temperature. It suggests that their contribution to the nitrate budget is well resolved, but this cannot be fully demonstrated from an observational basis since the only available nitrate data in the cold tongue area are from the PIRATA cruises which do not provide high-frequency information on the nutrient distribution. A dedicated study allowing better separation of the large-scale and eddying signals is needed in order to identify the nature of intraseasonal processes at work and their impact on the seasonal nitrate budget in the Atlantic cold tongue area.

\section{Conclusion}

We described and analyzed the seasonal cycle of nitrate and the associated physical processes in the Atlantic cold tongue 
region using in situ and satellite data and a coupled physicalbiogeochemical simulation. The model reproduces the horizontal and vertical patterns of chlorophyll observed in the studied area and its semiannual cycle. Nitrate required for the phytoplankton growth is supplied by vertical processes. The main supply period occurs from May to July and a secondary supply also occurs in November. In between, nitrate is removed by horizontal advection in August-September and during the secondary loss event in December-January. We draw attention to the potential roles of nitrate variations in the EUC and of intraseasonal processes in the seasonal nitrate budget.

Ding et al. (2009) put forward the presence of a basin mode that explains semiannual changes of sea surface height (SSH) gradient. Our results show how the thermocline and nitracline uplift affects the zonal nitrate gradient in the EUC and thus how it influences nitrate removal by horizontal advection and then vertical supply. Changes of the nitrate concentration in the source water within the NBUC may also impact nitrate changes in the center of the basin. A dedicated study of nitrate variations in the EUC and associated processes from the inflow in the western boundary current system to the equatorial upwelling region would contribute to better understanding phytoplankton variations in the equatorial Atlantic.

Our results suggest that eddy horizontal advection acts to remove nitrate while eddy vertical advection feeds both the mixed and euphotic layers with nitrate. Overall, eddy advection brings nitrate into the mixed and euphotic layers in JuneJuly and in November-December. To our knowledge, there are no studies on the role of TIWs and other intraseasonal processes on the equatorial Atlantic nitrate budget. This issue should be further investigated.

Data availability. PIRATA chemical data sets acquired during cruises are available through https://doi.org/10.17882/58141 (last access: 17 October 2017) (Bourlès et al., 2018a) and ADCP data are available through https://doi.org/10.17882/44635 (last access: 23 November 2018) (Bourlès et al., 2018c). ADCP mooring data are available through https://doi.org/10.17882/51557 (last access: 10 December 2018) (Bourlès et al., 2018b). The ocean color products of the GlobColour project are available through http://globcolour.info (last access: 30 January 2017). The TropFlux data are archived at https://www.incois.gov.in/tropflux (last access: 6 June 2017). Model results can be reproduced by using the ocean code nemo_v3_6 (http://forge.ipsl.jussieu.fr/40nemo/ wiki/Users, last access: 11 December 2017). The DFS5.2 forcing set is available on the server https://sextant.ifremer.fr/record/ c837b2f8-4152-41fd-8592-d4cd887d0b51/ (last access: 11 December 2017).

Author contributions. MHR and JJ designed the research study. JJ and CCT performed the numerical simulation with inputs from OA.
MHR conducted the analysis with help from JJ. MHR wrote the manuscript with contributions from all coauthors.

Competing interests. The authors declare that they have no conflict of interest.

Acknowledgements. We thank the IRD IMAGO team, Pierre Rousselot (ADCP), François Baurand (nutrients), and Sandrine Hillion (chlorophyll), for collecting, validating, and making available the French PIRATA cruise measurements, along with Jacques Grelet, Fabrice Roubaud, and other engineers and technicians of the PIRATA program for maintaining the ocean-atmosphere interaction buoys and ADCP moorings. We acknowledge the GlobColour and TropFlux projects for sharing the freely available data we use. GlobColour data have been developed, validated, and distributed by ACRI-ST, France. The TropFlux data are produced under a collaboration between Laboratoire d'Océanographie: Expérimentation et Approches Numériques (LOCEAN) from Institut Pierre Simon Laplace (IPSL, Paris, France) and the National Institute of Oceanography/CSIR (NIO, Goa, India) and supported by Institut de Recherche pour le Développement (IRD, France). TropFlux relies on data provided by the ECMWF Re-Analysis Interim (ERA-Interim) and ISCCP projects. Supercomputing facilities were provided by GENCI project GEN7298. We acknowledge Christian Ethé from the NEMO team for his help in setting up the configuration. This paper is dedicated to the memory of Christine Carine Tchamabi.

Review statement. This paper was edited by Emilio Marañón and reviewed by two anonymous referees.

\section{References}

Aiken, J., Brewin, R. J. W., Dufois, F., Polimene, L., HardmanMountford, N. J., Jackson, T., Loveday, B., Mallor Hoya, S., Dall'Olmo, G., Stephens, J., and Hirata, T.: A synthesis of the environmental response of the North and South Atlantic SubTropical Gyres during two decades of AMT, Prog. Oceanogr., 158, 236-254, 2017.

Athié, G. and Marin, F.: Cross-equatorial structure and temporal modulation of intraseasonal variability at the surface of the Tropical Atlantic Ocean, J. Geophys. Res., 113, C08020, https://doi.org/10.1029/2007JC004332, 2008.

Athié, G., Marin, F., Treguier, A.-M., Bourlès, B., and Guiavarc'h, C.: Sensitivity of near-surface Tropical Instability Waves to submonthly wind forcing in the tropical Atlantic, Ocean Model., 30, 241-255, 2009.

Aumont, O. and Bopp, L.: Globalizing results from ocean insitu iron fertilization experiments, Global Biogeochem. Cy., 20, GB2017, https://doi.org/10.1029/2005GB002591, 2006.

Aumont, O., Ethé, C., Tagliabue, A., Bopp, L., and Gehlen, M.: PISCES-v2: an ocean biogeochemical model for carbon and ecosystem studies, Geosci. Model Dev., 8, 2465-2513, https://doi.org/10.5194/gmd-8-2465-2015, 2015. 
Blanke, B., Arhan M., Lazar, A., and Prévost, G.: A Lagrangian numerical investigation of the origins and fates of the salinity maximum water in the Atlantic, J. Geophys. Res., 107, 3163, https://doi.org/10.1029/2002JC001318, 2002.

Bourlès, B.: PIRATA, https://doi.org/10.18142/14, 1997.

Bourlès, B., Gouriou, Y., and Chuchla, R.: On the circulation in the upper layer of the western equatorial Atlantic. J. Geophys. Res., 104, 21151-21170, 1999.

Bourlès, B., Brandt, P., Caniaux,G., Dengler, M., Gouriou, Y., Key, E., Lumpkin, R., Marin, F., Molinari, R. L., and Schmid, C.: African monsoon multidisciplinary analysis (AMMA): special measurements in the tropical Atlantic, CLIVAR Exchanges, 41, 7-9, 2007.

Bourlès, B., Lumpkin, R., McPhaden, M. J., Hernandez, F., Nobre, P., Campos, E., Yu, L., Planton, S., Busalacchi, A., Moura, A. D., Servain, J., and Trotte, J.: The PIRATA program: History, accomplishments, and future directions, B. Am. Meteorol. Soc., 89, 1111-1125, https://doi.org/10.1175/2008BAMS2462.1, 2008.

Bourlès, B., Baurand, F., Hillion, S., Rousselot, P., Grelet, J., Bachelier, C., Roubaud, F., Gouriou, Y., and Chuchla, R.: French PIRATA cruises: Chemical analysis data, SEANOE, https://doi.org/10.17882/58141, 2018a.

Bourlès, B., Habasque, J., Rousselot, P., Grelet, J., Roubaud, F., Bachelier, C., and Gouriou, Y.: French PIRATA cruises: Mooring ADCP data, SEANOE, https://doi.org/10.17882/51557, $2018 \mathrm{~b}$.

Bourlès, B., Herbert, G., Rousselot, P., and Grelet, J.: French PIRATA cruises: S-ADCP data, SEANOE, https://doi.org/10.17882/44635, 2018c.

Bourlès, B., Araujo, M., McPhaden, M. J., Brandt, P., Foltz, G. R., Lumpkin, R., Giordani, H., Hernandez, F., Lefèvre, N., Nobre, P., Campos, E., Saravanan, R., Trotte-Duhà, J., Dengler, M., Hahn, J., Hummels, R., Lübbecke, J. F., Rouault, M., Cotrim, L., Sutton, A., Jochum, M., and Perez, R. C.: PIRATA: A Sustained Observing System for Tropical Atlantic Climate Research and Forecasting, Earth and Space Science, 6, 577-616, https://doi.org/10.1029/2018EA000428, 2019.

Caltabiano, A. C. V., Robinson, I. S., and Pezzi, L. P.: Multi-year satellite observations of instability waves in the Tropical Atlantic Ocean, Ocean Sci., 1, 97-112, https://doi.org/10.5194/os-1-972005, 2005.

Caniaux, G., Giordani, H., Redelsperger, J.-L., Guichard, F., Key, E., and Wade, M.: Coupling between the Atlantic cold tongue and the West African monsoon in boreal spring and summer, J. Geophys. Res., 116, C04003, https://doi.org/10.1029/2010JC006570, 2011.

Carton, J. A. and Zhou, Z. X.: Annual cycle of sea surface temperature in the tropical Atlantic Ocean, J. Geophys. Res., 102, 27813-27824, 1997.

Christian, J. R. and Murtugudde, R.: Tropical Atlantic variability in a coupled physical-biogeochemical ocean model, Deep-Sea Res. Pt. II, 50, 2947-2969, 2003.

de Boyer Montégut, C., Madec, G., Fischer, A. S., Lazar, A., and Iudicone, D.: Mixed layer depth over the global ocean: An examination of profile data and a profilebased climatology, J. Geophys. Res., 109, C12003, https://doi.org/10.1029/2004JC002378, 2004.

de Coëtlogon, G., Janicot, S., and Lazar, A.: Intraseasonal variability of the ocean-atmosphere coupling in the Gulf of Guinea dur- ing boreal spring and summer, Q. J. Roy. Meteor. Soc., 136, 426441, https://doi.org/10.1002/qj.554, 2010.

Ding, H., Keenlyside, N. S., and Latif, M.: Seasonal cycle in the upper Equatorial Atlantic Ocean, J. Geophys. Res., 114, C09016, https://doi.org/10.1029/2009JC005418, 2009.

Dussin, R., Barnier, B., and Brodeau, L.: The making of Drakkar forcing set DFS5, DRAKKAR/MyOcean Report 01-04-16, LGGE, Grenoble, France, 2016.

Garcia, H. E., Locarnini, R. A., Boyer, T. P., Antonov, J. I., Zweng, M. M., Baranova, O. K., and Johnson, D. R.: World Ocean Atlas 2009, Volume 4: Nutrients (phosphate, nitrate, silicate), S. Levitus, Ed. NOAA Atlas NESDIS 71, U.S. Government Printing Office, Washington, D.C., 398 pp., 2010.

Gorgues, T., Menkes, C., Aumont, O., Vialard, J., Dandonneau, Y., and Bopp, L.: Biogeochemical impact of tropical instability waves in the equatorial Pacific, Geophys. Res. Lett., 32, L24615, https://doi.org/10.1029/2005GL024110, 2005.

Grodsky, S. A., Carton, J. A., and McClain, C. R.: Variability of upwelling and chlorophyll in the equatorial Atlantic, Geophys. Res. Lett., 35, L03610, https://doi.org/10.1029/2007GL032466, 2008.

Habasque, J. and Herbert, G.: Intercomparaison des mesures de courant dans l'Atlantique tropical, Rapport Coriolis, 65 pp., https://doi.org/10.13155/55134, 2018.

Hazeleger, W., de Vries, P., and Friocourt, Y.: Sources of the Equatorial Undercurrent in the Atlantic in a high resolution ocean model, J. Phys. Oceanogr., 33, 677-693, 2003.

Herbert, G. and Bourlès, B.: Impact of intraseasonal wind bursts on sea surface temperature variability in the far Eastern tropical Atlantic Ocean during boreal spring 2005 and 2006: focus on the mid-May 2005 event, Ocean Sci., 14, 849-869, https://doi.org/10.5194/os-14-849-2018, 2018.

Hernandez, O., Jouanno, J., and Durand, F.: Do the Amazon and Orinoco freshwater plumes really matter for hurricane-induced ocean surface cooling? J. Geophys. Res.-Oceans, 121, 21192141, https://doi.org/10.1002/2015JC011021, 2016.

Hernandez, O., Jouanno, J., Echevin, V., and Aumont, O.: Modification of sea surface temperature by chlorophyll concentration in the Atlantic upwelling systems, J. Geophys. Res.-Oceans, 122, 5367-5389, https://doi.org/10.1002/2016JC012330, 2017.

Hisard, P.: Variations saisonnières à l'équateur dans le Golfe de Guinée, Cahiers O.R.S.T.O.M., 11, 349-358, 1973.

Houghton, R. W. and Colin, C.: Wind-driven meridional heat flux in the Gulf of Guinea, J. Geophys. Res., 92, 10777-10786, 1987.

Jochum, M., Malanotte-Rizzoli, P., and Busalacchi, A.: Tropical instability waves in the Atlantic Ocean, Ocean Model., 7, 145-163, https://doi.org/10.1016/S1463-5003(03)00042-8, 2004.

Jouanno, J., Marin, F., du Penhoat, Y., Molines, J.-M., and Sheinbaum, J.: Seasonal modes of surface cooling in the Gulf of Guinea, J. Phys. Oceanogr., 41, 1408-1416, 2011 a.

Jouanno, J., Marin, F., du Penhoat, Y., Sheinbaum, J., and Molines, J.-M.: Seasonal heat balance in the upper $100 \mathrm{~m}$ of the equatorial Atlantic Ocean, J. Geophys. Res., 116, C09003, https://doi.org/10.1029/2010JC006912, 2011 b.

Jouanno, J., Marin, F., du Penhoat, Y., and Molines, J.-M.: Intraseasonal Modulation of the Surface Cooling in the Gulf of Guinea, J. Phys. Oceanogr., 43, 382-401, https://doi.org/10.1175/JPO-D12-053.1, 2013. 
Large, W. G. and Yeager, S.: The global climatology of an interannually varying air-sea flux data set, Clim. Dynam., 33, 341-364, https://doi.org/10.1007/s00382-008-0441-3, 2009.

Lefèvre, N.: Low $\mathrm{CO}_{2}$ concentrations in the Gulf of Guinea during the upwelling season in 2006, Mar. Chem., 113, 93-101, 2009.

Loukos, H. and Mémery, L.: Simulation of the nitrate seasonal cycle in the equatorial Atlantic ocean during 1983 and 1984, J. Geophys. Res., 104, 15549-15573, 1999.

Madec, G. and the NEMO team: NEMO ocean engine, Note du Pôle de modélisation No 27, Institut Pierre-Simon Laplace (IPSL), France, No 27, ISSN 1288-1619, 2016.

Marin, F., Caniaux, G., Bourlès, B., Giordani, H., Gouriou, Y., and Key, E.: Why were sea surface temperatures so different in the eastern equatorial Atlantic in June 2005 and 2006?, J. Phys. Oceanogr., 39, 1416-1431, 2009.

Maritorena, S., Hembise Fanton d'Andon, O., Mangin, A., and Siegel, D. A.: Merged satellite ocean color data products using a bio-optical model: characteristics, benefits and issues, Remote Sens. Environ., 114, 1791-1804, https://doi.org/10.1016/j.rse.2010.04.002, 2010.

Ménard, F., Fonteneau, A., Gaertner, D., Nordstrom, V., Stéquert, B., and Marchal, E.: Exploitation of small tunas by a purse-seine fishery with fish aggregating devices and their feeding ecology in an eastern tropical Atlantic ecosystem, ICES J. Mar. Sci., 57, 525-530, 2000.

Menkes, C., Kennan, S. C., Flament, P., Dandonneau, Y., Masson, S., Biessy, B., Marchal, E., Eldin, G., Grelet, J., Montel, Y., Morlière, A., Lebourges-Dhaussy, A., Moulin, C., Champalbert, G., and Herbland, A.: A whirling ecosystem in the Equatorial Atlantic, Geophys. Res. Lett., 11, 1553, https://doi.org/10.1029/2001GL014576, 2002.

Menkes, C., Vialard, J., Kennan, S. C., Boulanger, J.-P., and Madec, G.: A modeling study of the impact of tropical instability waves on the heat budget of the eastern equatorial Pacific, J. Phys. Oceanogr., 36, 847-865, 2006.

Merle, J.: Seasonal heat budget in the equatorial Atlantic Ocean, J. Phys. Oceanogr., 10, 464-469, 1980.

Monger, B., McClain, C., and Murtugudde, R.: Seasonal phytoplankton dynamics in the eastern tropical Pacific, J. Geophys. Res., 102, 12389-12411, 1997.

Morel, A. and Berthon, J.-F.: Surface pigments, algal biomass profiles, and potential production of the euphotic layer: relationships investigated in view of remote-sensing applications, Limnol. Oceanogr., 34, 1545-1562, 1989.

Morlière, A., le Bouteiller, A., and Citeau, J.: Tropical instability waves in the Atlantic Ocean: a contributor to biological processes, Oceanol. Acta, 17, 585-596, 1994.

Nubi, O. A., Bourlès, B., Edokpayi, C. A., and Hounkonnou, M. N.: On the nutrient distribution and phytoplankton biomass in the Gulf of Guinea equatorial band as inferred from in-situ measurements, J. Oceanogr. Mar. Sci., 7, 1-11, https://doi.org/10.5897/JOMS2016.0124, 2016.

Okumura, Y. and Xie, S.-P.: Some overlooked features of tropical Atlantic climate leading to a new Nino-like phenomenon, J. Climate, 19, 5859-5874, https://doi.org/10.1175/JCLI3928.1, 2006.

Oudot, C.: La distribution des sels nutritifs $\left(\mathrm{NO}_{3}-\mathrm{NO}_{2}-\mathrm{NH}_{4}-\mathrm{PO}_{4}\right.$ $\mathrm{SiO}_{3}$ ) dans l'Océan Atlantique intertropical oriental (région du golfe de Guinée), Océanographie Tropicale, 18, 223-248, 1983.
Oudot, C. and Morin, P.: The distribution of nutrients in the equatorial Atlantic: relation to physical processes and phytoplankton biomass, Oceanol. Acta, Proceedings International Symposium on Equatorial Vertical Motion, 6-10 May 1985, Paris, 121-130, 1987.

Perez, R. C., Hormann, V., Lumpkin, R., Brandt, P., Johns, W. E., Hernandez, F., Schmid, C., and Bourlès, B.: Mean meridional currents in the central and eastern equatorial Atlantic, Clim. Dynam., 43, 2943-2962, https://doi.org/10.1007/s00382-013-1968$5,2014$.

Perez, R. C., Foltz, G. R., Lumpkin, R., and Schmid, C.: Direct measurements of upper ocean horizontal velocity and vertical shear in the tropical North Atlantic at $4^{\circ} \mathrm{N}, 23^{\circ} \mathrm{W}, \mathrm{J}$. Geophys Res.-Oceans, 124, 4133-4151, https://doi.org/10.1029/2019JC015064, 2019.

Pérez, V., Fernández, E., Marañón, E., Serret, P., and García-Soto, C.: Seasonal and interannual variability of chlorophyll a and primary production in the Equatorial Atlantic: in situ and remote sensing observations, J. Plankton Res., 27, 189-197, 2005.

Peter, A.-C, le Hénaff, M., du Penhoat, Y., Menkes, C., Marin, F., Vialard, J., Caniaux, G., and Lazar, A.: A model study of the seasonal mixed layer heat budget in the equatorial Atlantic, J. Geophys. Res., 111, C06014, https://doi.org/10.1029/2005JC003157, 2006.

Praveen Kumar, B., Vialard, J., Lengaigne, M., Murty, V. S. N., and McPhaden, M. J.: TropFlux: air-sea fluxes for the global tropical oceans - Description and evaluation, Clim. Dynam., 38, 15211543, https://doi.org/10.1007/s00382-011-1115-0, 2012.

Resplandy, L., Lévy, M., Bopp, L., Echevin, V., Pous, S., Sarma, V. V. S. S., and Kumar, D.: Controlling factors of the oxygen balance in the Arabian Sea's OMZ, Biogeosciences, 9, 50955109, https://doi.org/10.5194/bg-9-5095-2012, 2012.

Servain, J., Busalacchi, A. J., McPhaden, M. J., Moura, A. D., Reverdin, G., Vianna, M., and Zebiak, S. E.: A Pilot Research Moored Array in the Tropical Atlantic (PIRATA), B. Am. Meteorol. Soc., 79, 2019-2031, 1998.

Signorini, S. R., Murtugudde, R. G., McClain, C. R., Christian, J. R., Picaut, J., and Busalacchi, A. J.: Biological and physical signatures in the tropical and sub-tropical Atlantic, J. Geophys. Res., 104, 18367-18382, 1999.

Storto, A., Masina, S., Simoncelli, S., Iovino, D., Cipollone, A., Drevillon, M., Drillet, Y., von Schuckman, K., Parent, L. Garric, G., Greiner, E., Desportes, C., Zuo, H., Balmaseda, M. A., and Peterson, K. A.: The added value of the multi-system spread information for ocean heat content and steric sea level investigations in the CMEMS GREP ensemble reanalysis product, Clim. Dynam., 53, 287, https://doi.org/10.1007/s00382-0184585-5, 2018.

Strutton, P. G., Ryan, J. P., and Chavez, F. P.: Enhanced chlorophyll associated with tropical instability waves in the equatorial Pacific, Geophys. Res. Lett., 28, 2005-2008, 2001.

Vialard, J. and Delecluse, P.: An OGCM study for the TOGA decade. Part I: Role of salinity in the physics of the western Pacific fresh pool, J. Phys. Oceanogr., 28, 1071-1088, 1998.

Vialard, J., Menkes, C., Boulanger, J.-P., Delecluse, P., Guilyardi, E., McPhaden, M. J., and Madec, G.: A model study of oceanic mechanisms affecting equatorial Pacific sea surface temperature during the 1997-98 El Niño, J. Phys. Oceanogr., 31, 1649-1675, 2001. 
Voituriez, B.: Les variations saisonnières des courants équatoriaux à $4^{\circ} \mathrm{W}$ et l'upwelling équatorial du golfe de Guinée: 1 . Le souscourant équatorial, Océanographie Tropicale, 18, 163-183, 1983.

Voituriez, B. and Herbland, A.: Etude de la production pélagique de la zone équatoriale de l'Atlantique à $4^{\circ} \mathrm{W}$ : 1 . Relations entre la structure hydrologique et la production primaire, Cahiers ORSTOM.Série Océanographie, 15, 313-331, 1977.
Voituriez, B. and Herbland, A.: Signification de la relation nitrate/température dans l'upwelling équatorial du Golfe de Guinée, Oceanol. Acta, 7, 169-174, 1984.

White, R. H.: Using multiple passive tracers to identify the importance of the North Brazil undercurrent for Atlantic cold tongue variability, Q. J. Roy. Meteor. Soc., 141, 2505-2517, https://doi.org/10.1002/qj.2536, 2015. 